\title{
Linear infrastructure impacts on landscape hydrology
}

Keren G Raiter ${ }^{1,2}$, Suzanne M Prober ${ }^{2,1}$, Hugh P Possingham ${ }^{3,4}$, Fiona Westcott ${ }^{5}$ \& Richard J Hobbs $^{1}$

1 School of Biological Sciences, University of Western Australia, 35 Stirling Hwy Crawley, Perth, WA, 6009, Australia

2 CSIRO Land and Water, Private Bag 5, Wembley Perth, WA, 6913, Australia

3 The Nature Conservancy, 4245 North Fairfax Drive, Suite 100 Arlington, VA 22203, USA

4 School of Biological Sciences, University of Queensland St Lucia, Brisbane, Qld, 4072, Australia

\section{Corresponding author}

Keren Raiter, Department of Ecology, Evolution and Behavior, Hebrew University of Jerusalem, Givat Ram, Jerusalem, Israel. Email: keren.raiter@mail.huji.ac.il/keren.raiter@me.com

\section{Citation for this article}

Raiter, K.G., Prober, S.M., Possingham, H.P., Westcott, F., Hobbs, R.J., 2018. Linear infrastructure impacts on landscape hydrology. Journal of Environmental Management 206, 446-457. https://doi.org/10.1016/j.jenvman.2017.10.036.

\section{Copyright statement}

(C) 2018. Original research article. This is the accepted author manuscript. The final version is available at Elsevier at: https://doi.org/10.1016/i.jenvman.2017.10.036 . This manuscript version is made available under the CC-BY-NC_ND 4.0 licence https://creativecommons.org/licenses/by-nc-nd/4.0/.

\section{Keywords}

Surface hydrology; road ecology; road impacts; soil erosion; semi-arid; Great Western Woodlands. 


\section{Highlights}

- Worldwide, linear infrastructure proliferation alters surface hydrology

- Roads and railways frequently intercept, channelize, and/or impede flows

- Erosion and pooling are 5 and 6 times as likely to occur on-road than off-road

- Linear infrastructure affects ephemeral stream flows at $98 \%$ of crossings

- There is substantial scope for mitigating the hydrological impacts observed

\section{Abstract}

The extent of roads and other forms of linear infrastructure is burgeoning worldwide, but their impacts are inadequately understood and thus poorly mitigated. Previous studies have identified many potential impacts, including alterations to the hydrological functions and soil processes upon which ecosystems depend. However, these impacts have seldom been quantified at a regional level, particularly in arid and semi-arid systems where the gap in knowledge is the greatest, and impacts potentially the most severe.

To explore the effects of extensive track, road, and rail networks on surface hydrology at a regional level we assessed over $1000 \mathrm{~km}$ of linear infrastructure, including approx. 300 locations where ephemeral streams crossed linear infrastructure, in the largely intact landscapes of Australia's Great Western Woodlands. We found a high level of association between linear infrastructure and altered surface hydrology, with erosion and pooling 5 and 6 times as likely to occur on-road than off-road on average (1.06 erosional and 0.69 pooling features $\mathrm{km}^{-1}$ on vehicle tracks, compared with 0.22 and 0.12 $\mathrm{km}^{-1}$, off-road, respectively). Erosion severity was greater in the presence of tracks, and $98 \%$ of crossings of ephemeral streamlines showed some evidence of impact on water movement (flow impedance (62\%); diversion of flows (73\%); flow concentration (76\%); and/or channel initiation (31\%)). Infrastructure type, pastoral land use, culvert presence, soil clay content and erodibility, mean annual rainfall, rainfall erosivity, topography and bare soil cover influenced the frequency and severity of these impacts.

We conclude that linear infrastructure frequently affects ephemeral stream flows and intercepts natural overland and near-surface flows, artificially changing site-scale moisture regimes, with some parts of the landscape becoming abnormally wet and other parts becoming water-starved. In addition, linear infrastructure frequently triggers or exacerbates erosion, leading to soil loss and degradation. Where linear infrastructure densities are high, their impacts on ecological processes are likely to be considerable. Linear infrastructure is widespread across much of this relatively intact region, but there remain areas with very low infrastructure densities that need to be protected from further impacts. There is substantial scope for mitigating the impacts of existing and planned infrastructure developments.

\section{Introduction}

Linear infrastructure such as roads, tracks, railways and pipelines are pervasive features of even relatively undisturbed landscapes, and can affect the soil, hydrologic, and biotic processes upon which ecosystems depend. However, their impacts on ecological functions and processes within these landscapes are not generally well understood, with particularly little quantification of how linear 
infrastructure affects the movement of water across landscapes. Rather, most studies of the environmental impacts of linear infrastructure focus on the effects of roads on wildlife and on fragmentation of the landscape from a biotic perspective (Duniway et al., 2010; Wang et al., 2014). This lack of data has led to predominantly descriptive rather than analytical and predictive planning and evaluation of hydro-ecological impacts, limiting the development of useful baselines and prognoses of potentially serious impacts (Karlson and Mortberg, 2015). Indeed, Duniway and Herrick (2013) named linear infrastructure 'one of the most pressing rangeland management concerns in arid and semi-arid lands globally'.

Hydrologic impacts of linear infrastructure can be subtle but may extend over large areas, wellbeyond the direct infrastructure footprint. They are generally a consequence of excess overland flow generated along relatively impermeable and unvegetated road surfaces, interception of overland or subsurface flows from upslope areas, and altered stream flows (Duniway and Herrick, 2011; King and Tennyson, 1984; Montgomery, 1994). Key impacts include erosion and vegetation changes in areas of increased runoff, altered stream function, and downslope starvation due to interception of flows; each with their own cascading or feedback effects.

Increased runoff

Increased runoff resulting from reduced infiltration into the surfaces of linear infrastructure can be a major cause of chronic erosion, both along the linear infrastructure corridor and downslope of it; while some erosion can even move upstream (Donaldson et al., 2004; Duniway and Herrick, 2011; Montgomery, 1994; Ziegler et al., 2001). Excess flows can potentially breach road edges and flow downslope, initiating channel formation downstream of the road where no channel existed naturally (Katz et al., 2014; Montgomery, 1994). Excess surface water can also pool in roadway depressions, enter subsurface soil profiles and produce minor landslides and slope instability (Montgomery, 1994). Erosion and increased water availability in proximity to linear infrastructure affect a range of ecological functions and processes (Duniway and Herrick, 2011).

\section{Sheetflow interception}

Interception of sheetflow (also called Hortonian overland flow; Montgomery, 1994) and subsurface flows from upslope areas can also cause water to concentrate or pool on linear infrastructure or immediately upstream of it, or be laterally redistributed (Duniway and Herrick, 2011; Luce, 2002; Switalski et al., 2004). This can starve downstream areas that would have otherwise received the flow, with sometimes severe effects on downstream vegetation communities (Duniway and Herrick, 2011; Waddell et al., 2012).

\section{Altered stream flows}

Water flow in streams can also be altered through impeding, concentrating, channelling, and/or intercepting of water by linear infrastructure, with consequences for stream functional health and stability and for soil and organic matter movement (Donaldson et al., 2004; King and Tennyson, 1984; Montgomery, 1994). Excess overland runoff on linear infrastructure can also enter streams, changing flow regimes far downslope. Artificially high flows can also cause significant downstream erosion and gully incision, particularly given highly erosive, high-velocity flows that may result from on-road runoff generation (Luce, 2002; Wemple et al., 1996).

These different effects of linear infrastructure on hydrological processes can result in feedbacks or synergistic interactions with other stressors that further degrade the hydrological integrity of a 
landscape. For example, reduced vegetation productivity in areas starved of sheetflow provides less protection of soil surfaces from UV and raindrop impacts, leading to soil crusting and reduced infiltration and hence further diminishing the available water in that area (Duniway and Herrick, 2011). Similarly, a dense network of linear infrastructure in a catchment can act synergistically with other activities facilitated by that infrastructure, such as reduced vegetation cover following timber harvesting, producing larger and higher energy flows, with increased erosion and soil loss (Bruijnzeel and Vertessy, 2004).

Hydrologic impacts of linear infrastructure will also be influenced by the characteristics of the environment which they pass through, including rainfall, topography, soils and vegetation cover (Huang et al., 2013; Katz et al., 2014; Webb et al., 2014). Beyond environmental factors, linear infrastructure type, location, orientation to slope, density, and design can all affect the type and degree of impacts (Katz et al., 2014; Keshkamat et al., 2013; Pechenick et al., 2014; Wang et al., 2014).

In this paper we present a regional-level evaluation of the effects of linear infrastructure on surface and near-surface hydrology. We aimed to characterise and quantify the range of impacts observed in in the semi-arid landscapes of south-western Australia's Great Western Woodlands (GWW), and to identify underlying drivers of these impacts. The 16 million ha GWW is the largest intact temperate woodland left on Earth and a region of global biodiversity significance, and the driest temperate area in the world in which extensive tracts of woodland occur (Prober et al., 2012; Watson et al., 2008). To achieve this, we used a combination of field-based assessments and GIS techniques to test the following hypotheses:

Hypothesis 1: Indications of altered water movement (erosion and pooling frequency, and erosion severity) are associated with linear infrastructure, and increase with increased engineering of the infrastructure

Hypothesis 2: The probability that linear infrastructure will impact on ephemeral streams increases with level of engineering of the infrastructure, for each of the following categories of impact:

a) flow impedance

b) flow diversion (away from natural course)

c) flow concentration

d) stream channel initiation (as a result of flow concentration or diversion)

We also aimed to quantify the regional extent of infrastructure impacts on surface hydrological processes in the GWW, and identify options for mitigating those impacts.

\section{Methods}

\subsection{Study area}

The GWW is situated in the interzone between the mesic south-west corner of Western Australia, and the continent's arid interior (Figure 1). It comprises a mosaic of vegetation types and landforms including salt lakes, banded ironstone formations, and rock outcrops. The landscape is ancient, deeply weathered, and very subdued except around banded ironstone formations, with shrublands typically 
occurring in higher parts of the landscape on deep sands, and woodlands predominating on lower parts of the landscape on red clay or duplex (loam over clay) soils (Berry et al., 2010; Burnside et al., 1995; Prober et al., 2012). The region has a low and variable rainfall, with mean annual averages ranging from approximately $400 \mathrm{~mm}$ in the south-west to $200 \mathrm{~mm}$ in the north-east (Prober et al., 2012). Rainfall is winter-dominant in the south-west, but this pattern declines toward the northeast where average winter and summer rainfalls are similar.

The low, variable rainfall, combined with ancient and deeply weathered geology and subdued topography, result in a landscape hydrology characterised by gentle overland sheetflow (particularly on more clayey soils; Burnside et al., 1995), and surface drainage along ephemeral streams into large disconnected chains of salt lakes. These lakes are mainly internally draining but link up and flow into one another during exceptionally wet years. They are often underlain by paleochannels which formed mainly during the Jurassic and Eocene, and shallower alluvial valley floor aquifers that are mainly hypersaline (Braimbridge and Commander, 2005).

Water availability is probably the dominant driver of vegetation productivity in the GWW, and there is strong edaphic and topographic control of vegetation community and structure (Burnside et al., 1995; Prober et al., 2012). The GWW has low levels of soil compaction and abundant ant and termite fauna; features which generally promote soil water infiltration (Prober et al., 2012).

The GWW has largely escaped broad-scale clearing for agriculture because of its limited water resources and historical circumstances, although many parts have still experienced impacts of human activities and exotic species invasions (Prober et al., 2012). Mineral production and timber extraction from the area has created, and continues to create, an extensive network of roads, tracks, pipelines and railways. Cattle and sheep pastoralism, covering $30 \%$ of the area, has reduced the abundance of more palatable shrubs, damaged biological soil crusts, increased soil compaction and reduced infiltration resulting in increased overland water flow and soil erosion, particularly around watering points (Burnside et al., 1995).

\subsection{Assessment method}

Field observations were made along over $1,000 \mathrm{~km}$ of linear infrastructure and undisturbed vegetation in the western half of the GWW. The study route traversed a large portion of the GWW and encompassed a broad range of vegetation and soil types, landforms, and different types of linear infrastructure. Qualitative and quantitative observations were focused on identifying instances of altered, enhanced, or reduced water movement (Figure 2). All assessments were conducted by KR, with discussion and input from F. Westcott. 


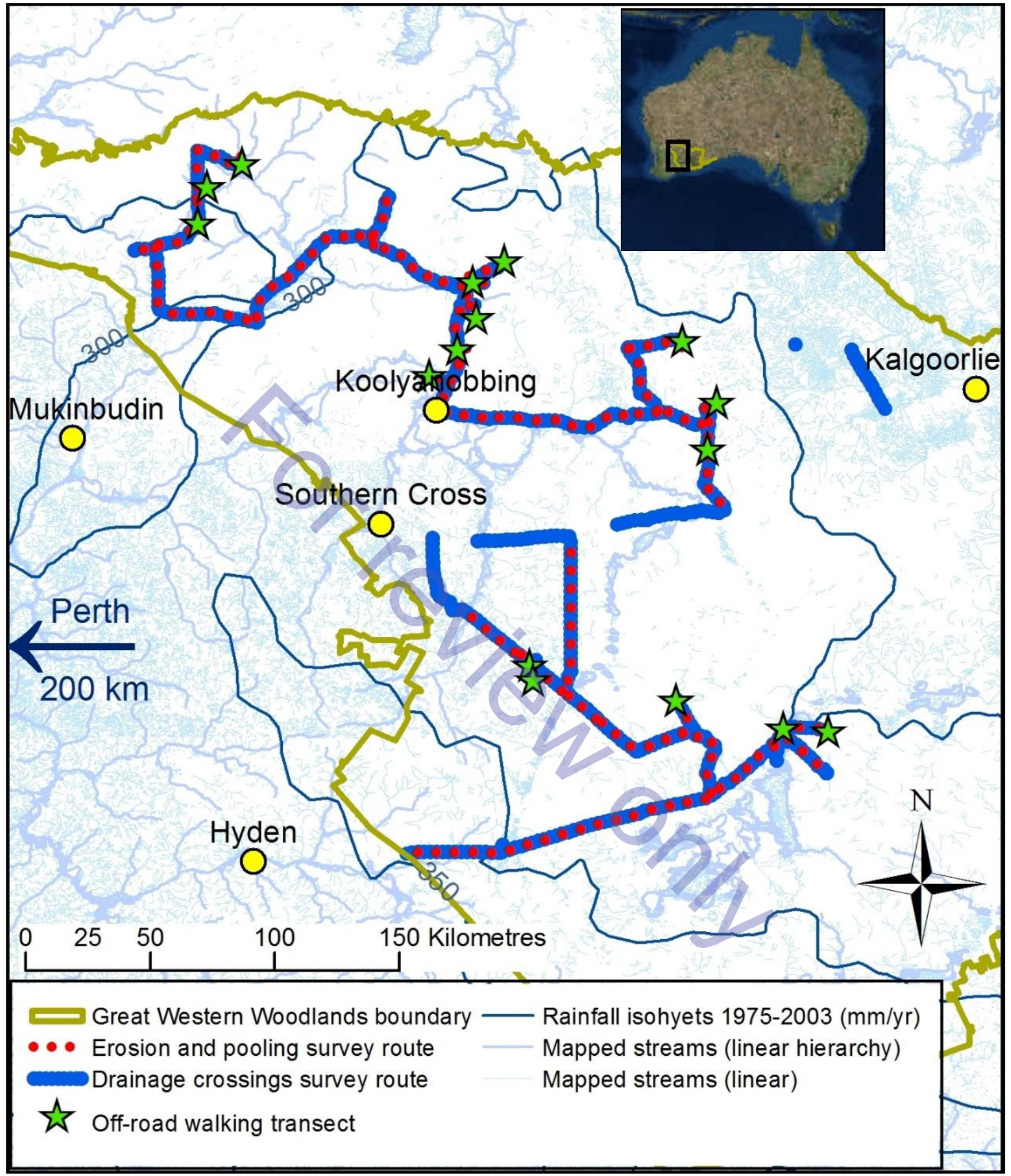

Figure 1: Study area, the western portion of the Great Western Woodlands of south-western Australia, showing study routes for the 'erosion and pooling' and the 'drainage crossing' assessments. 


\subsection{Erosion and pooling assessment}

To examine the impact of linear infrastructure on landscape surface water movement (hypothesis 1), we recorded erosional and pooling features along $101 \mathrm{~km}$ of standard gauge railway, $340 \mathrm{~km}$ of graded, unpaved roads, $377 \mathrm{~km}$ of major tracks (bladed unpaved roads) and $217 \mathrm{~km}$ of minor tracks (unbladed vehicle tracks often consisting of two wheel ruts through largely undisturbed vegetation, or previously bladed tracks that have degraded to 'two wheel rut' condition). This assessment occurred in July 2014. Recordings were made while driving at speeds of generally $10-40 \mathrm{kmhr}^{-1}$, with on-foot examinations where required. Descriptions and examples of each type of linear infrastructure are presented in Supplemental Material - Appendix 1. We also walked through undisturbed vegetation along sixteen off-road transects averaging $7 \mathrm{~km}$ each (total $110 \mathrm{~km}$ ), to constitute an off-linearinfrastructure control. Each transect consisted of walking perpendicular to a road to a pre-specified point 3-5 $\mathrm{km}$ away (and $>3 \mathrm{~km}$ from any other road), and returning via an alternative route.

We recorded coordinates of all water-erosional features and sites where pooling was evident (even if water was not present at the time of observation) using handheld GPS units. Erosional features were classified into one of four categories on the following scale of severity, adapted from Tongway and Ludwig (2010): 1) rill to $5 \mathrm{~cm}$ deep, $>2 \mathrm{~m}$ long; 2) rill to $15 \mathrm{~cm}$ deep, $>10 \mathrm{~m}$ long; 3) rills to $30 \mathrm{~cm}$ deep, $>20 \mathrm{~m}$ long, 4) gullies deeper than $30 \mathrm{~cm}$. Locations were recorded where the road surface had been actively maintained and thus concealed erosion and pooling, where a road had been rerouted to avoid severe and unnavigable pooling and erosion, or where road engineering had taken place to address severe pooling (i.e. filling in depression with gravel or sand). In addition, pastoral tenure and evidence of feral cattle grazing (e.g. cattle prints, droppings, or live sightings) outside of pastoral tenure were recorded, leading to three grazing categories in the erosion and pooling assessments: ungrazed, pastoral-grazed, and feral-grazed. Lastly, stretches of road where bare ground and erosional pedestals and terracettes indicated the existence of sheetflow intersected by the infrastructure were also recorded.

\subsection{Drainage crossings assessments}

Linear infrastructure impacts on drainage crossings (hypothesis 2) were assessed across 304 observed or suspected drainage crossings along a total of $101 \mathrm{~km}$ of railway, $81 \mathrm{~km}$ of paved roads (including a highway), $341 \mathrm{~km}$ of unpaved road, $375 \mathrm{~km}$ of major track and $217 \mathrm{~km}$ of minor track. This assessment occurred over 3 trips to the area: in October 2012, March-April 2014, and July 2014. We assessed all stream crossings on our route as previously identified from two hydrography datasets ("Hydrography, Linear" and "Hydrography, Linear (hierarchy)", Western Australian Department of Water), as well as any additional natural or constructed drainage lines encountered.

Our impact classification system was adapted from Duniway and Herrick (2011), the ephemeral drainage-line assessment protocol of Tongway and Hindley (2004; a component of landscape functional analysis), and the concept of channel initiation described by Montgomery (1994). The ephemeral drainage-line assessment evaluates the stability of ephemeral drainage lines as a key indicator of their status and that of the surrounding area, based on the premise that landscapes selforganise to conserve and utilise scarce resources (Tongway and Ludwig 2010). 




Figure 2: Examples of linear infrastructure impacts on surface water hydrology. a) Gully erosion along a track caused by large amounts of fast-moving water produced on-road during rainfall events and/or intercepted from upslope overland or subsurface flows. b) A track that is lower than the surrounding ground level has become a drainage channel. c) Three locations $\mathbf{4 0 0} \mathrm{m}$ apart along a track where sheetflow from upslope (right of image) appears to have been intercepted by the track, and concentrated into the three drainage outfalls indicated by the arrows. The arrows also show the direction of flow. Vegetation on the downslope (left) side of the track in the lower part of the image appears sparse and may be suffering from water starvation. d) A small eroded channel initiated by a track along which water movement is evident. There is no channel upslope of the track. e) Pooling along a track has created an unnatural water source which has attracted emus (Dromaius novaehollandiae). Wildlife attracted to water along infrastructure are at greater risk of road mortality, and increasing the temporal availability of water for fauna may cause other ecological changes. f) A windrow on the upslope side of a track which intercepted sheetflow and caused upslope pooling, until the windrow was breached and the water flowed onto the track - now in a concentrated fashion. g) Large area of pooling along a track. Such pools can stay wet for many days after the surrounding landscape has dried. Such obstructions to traffic often cause drivers to create alternative vehicle tracks to drive around, causing further disturbance and increasing the total road footprint. In this case the detour track is also flooded and additional detour tracks may result. Images: A, B, D, E, F: Keren Raiter. C: Google Earth. G: Carl Gosper. 
At each drainage crossing, we performed a brief assessment of impacts on water flow on each side of the road using evidence of water pooling and movement in ground surface morphology (e.g. existence of rills, depressions, and channels), vegetation and litter. Impacts were classified as i) flow impedance, ii) flow diversion, iii) flow concentration and/or iv) channel initiation. Areas upstream of linear infrastructure were regarded as controls for comparison with areas downstream, except where the streamline immediately upstream from the infrastructure was affected by it (e.g. pooling upstream of road, undercutting of upstream bank, earthworks). Where this exception occurred, we walked upstream to find a suitable 'control' area.

We recorded vegetation type, grazing status, presence of engineered solutions to hydrological flow issues (e.g. culverts, mitre drains), along with descriptions of the stream channel. We also conducted detailed drainage-line assessments on two case-study streams selected to characterise impacts, following Tongway and Hindley (2004). In these, indices of drainage-line stability were calculated for stream segments based on eight indicators of stability, including cross-sectional shape of channel, longitudinal profile, and vegetation on channel floors and walls (details available at: http://alturl.com/5bpyg).

\subsection{Analysis}

Datasets produced and analysed in the course of this study are

available online (see Raiter, 2017; available at http://dx.doi.org/10.17632/b7xpsmwb4s.2). We compiled a spatial database of the observations of erosion, pooling, and ephemeral stream crossings on ArcGIS 10.2. We generated a range of explanatory variables to represent the following key hypothesised drivers of impacts: topography (topographic wetness, localised topographic depression, slope, topographic roughness), climate (annual mean precipitation and evaporation, rainfall seasonality and erosivity, average runoff), soil (soil clay percentage, soil coarse fragments, soil erodibility, soil water holding capacity, geology), and vegetation (enhanced vegetation condition index, normalised difference vegetation index, bare soil percentage). Variables were calculated using $\sim 30 \mathrm{~m}$ resolution hydrologically conditioned and drainage enforced digital elevation models provided by Geosciences Australia or extracted from the Atlas of Living Australia and are described in further detail in Supplemental material -Appendix 2.

Response variables consisted of erosion and pooling frequency and erosion severity for the erosion and pooling assessment, and occurrence of flow impedance, diversion, concentration, and stream channel initiation at stream crossings, for the drainage crossing assessment. To quantify the frequency of erosion and pooling features in relation to the paths assessed, we counted erosional and pooling features observed along each of 1110, $1 \mathrm{~km}$ segments of the study route using Geospatial Modelling Environment (Version 0.7.3.0 Beyer, 2012).

We excluded all observations where the road surface had been recently graded and/or otherwise maintained, as erosional or pooling features would have been obscured. As a consequence, all of the railways, and (paved and unpaved) roads were excluded from the erosion and pooling frequency and erosion severity analyses, leaving only minor and major tracks. We excluded 19 sites from the drainage crossings analysis where a stream had been mapped but was not observed on the ground.

Data exploration was carried out by box and scatterplots, to assess the presence of outliers and investigate relationships between variables. Relationships between covariates were assessed using 
Pearson correlation coefficients, and combinations of highly collinear covariates were avoided in the analysis.

We tested all of the hypotheses using classification and regression trees; a non-parametric machinelearning statistical analysis technique in which the predictor space is recursively partitioned and a simple prediction model is fitted within each partition. Classification and regression trees do not impose linearity, automatically model interactions among predictors, and can be represented graphically as decision trees, allowing easy interpretation (James et al., 2013).

We created conditional inference trees using the method of Hothorn et al. (2006), in the 'party' package (available at http://party.r-forge.r-project.org) performed in R software (version 3.1.2, R Core Team, 2015). The conditional inference tree approach is advantageous over more traditional classification and regression trees as it uses a statistical approach to recursive partitioning which takes into account the distributional properties of the measures and thus removes selection bias towards covariates with many possible splits. Conditional inference trees also use statistical significance thresholds and stopping rules (here: $p<0.05$ ) which avoid overfitting, the need for cross-validation and pruning, and reliance on an arbitrary threshold of 'impurity'. For each hypothesis, conditional inference trees were first produced using only infrastructure type as the predictor, and then with the full suite of potential predictors included. Further information on the model development are provided in Appendix 3. We also used the Welch Two-sample T test in R (base package) to test for differences between on-road and off-road frequencies of erosion and pooling.

An additional analysis using boxplots and ANOVAs was performed to test for possible compounding of the effects of linear infrastructure and grazing (Appendix 4). This analysis concluded that grazing (both feral and pastoral) was consistently associated with more frequent and severe erosion within linear infrastructure categories, as was pooling in most cases. Thus both grazing and linear infrastructure were included as independent variables in all analyses.

Lastly, we used a quantification of linear infrastructure across the GWW by Raiter et al. (2017) to estimate erosional and pooling features, and linear infrastructure impacts on ephemeral streamlines within the region. The quantification combined 23 unique existing datasets of linear infrastructure and further digitised unmapped disturbance features that were visible in aerial imagery across 24 stratified near-random sample areas. Our estimates were based on the erosion, pooling and ephemeral stream crossing impact rates observed, and did not take into account environmental predictor variables.

\section{Results}

\subsection{Erosion and pooling frequency, and erosion severity (hypothesis 1)}

We recorded 808 erosional features and 476 pooling features along the $1145 \mathrm{~km}$ study route. Of these, 652 erosional features and 368 pooling features were on tracks, and 39 and 15 were observed off-road, respectively. The presence of linear infrastructure thus emerged as a major factor in determining their occurrence, with an average of 1.06 erosional features per kilometre on-road compared with an average of 0.22 erosional features per kilometre off-road (Welch T-test: $t=-11.4$, $p<0.0001)$. Similarly, an average of 0.69 pooling features per kilometre were observed on-road compared with 0.12 off-road (Welch T-test: $t=-9.8, p<0.0001)$. Due to regular maintenance on 
railways and roads, the comparison of different levels of road engineering on altered water movement was limited to comparing major and minor tracks.

\subsection{Erosion frequency}

The conditional inference tree indicated that erosion was primarily determined by grazing status $(p<0.001)$, with erosion significantly more likely to occur in areas either under grazing tenure, or where feral cattle occur (average of 1.9 erosional features per km; Figure 3a). In ungrazed areas (average of 0.8 erosional features per $\mathrm{km}$ ), the presence of linear infrastructure was the next determinant of erosion frequency with 0.7 erosional features off-road compared with 0.9 erosional features on-road, on average $(p<0.001)$. In ungrazed areas in the presence of linear infrastructure, greater topographic slope, average annual precipitation, and soil clay proportion, all significantly increased the expected frequency of erosional features (all $p$ values $<0.001$ ).

\subsection{Pooling frequency}

Pooling was firstly determined by average annual rainfall, with greater frequency of pooling in wetter areas (rain $\geq 277 \mathrm{~mm} ; \mathrm{p}<0.001$; Figure $3 \mathrm{~b}$ ). The type of linear infrastructure was the next most significant determinant of pooling frequency, although the breakdown varied: in wetter areas, major and minor tracks both predicted significantly higher pooling than off-road areas, with 1.1 and 0.06 pooling features per $\mathrm{km}$, respectively $(\mathrm{p}<0.001)$. In contrast, in drier areas, major tracks had significantly more pooling than both minor tracks and off-road areas combined ( $p>0.001)$. Pooling along major tracks in drier areas was more frequent where the soil clay proportion was greater than $30 \%(p<0.001)$, and otherwise was greater where slope was below $\sim 1 \%(p<0.003)$. Pooling along minor tracks and in off-road areas in drier areas (rain $\leq 277 \mathrm{~mm}$ ) was again partitioned by soil clay proportion: greater soil clay content predicted more frequent pooling $(p<0.001)$.

\subsection{Erosion severity}

Erosion severity was higher in the presence of tracks ( $p=0.014$, Welch Two Sample t-test); the median on-road severity was 2 (rill to $15 \mathrm{~cm}$ deep, >10 m long) whereas the median off-road severity was 1 (rill to $5 \mathrm{~cm}$ deep, 2-10 $\mathrm{m}$ long). However, the effect of linear infrastructure on erosion severity only emerged as significant when this was tested for alone. The full conditional inference tree analysis identified slope, soil erodibility and bare soil percentage as sufficiently explaining the variation observed in the data, with greater slope, soil erodibility, and bare soil percentage all predicting more severe erosion ( $p<0.002$; Appendix 5, Figure A5.1a).

\subsection{Drainage crossings (hypothesis 2)}

Out of 285 drainage crossings assessed over $1119 \mathrm{~km}$ of linear infrastructure: 176 (62\%) showed signs of flow impedance, 209 (73\%) showed diversion of flows, 219 (76\%) showed concentration of flows, and 88 (31\%) showed channel initiation. Regarding design and construction attributes, 113 had culverts; 4 had flattened windrows; 112 had mitre drains; 5 had armoured pools, 5 had road diversions, and 154 had no engineering to facilitate stream continuation. Two of the culverts observed were blocked with sediment. On one stretch of road, we found three examples where culverts had been installed where there was no flow, whereas the actual streamlines (often within 1 $\mathrm{km}$ away) had no culverts and were blocked by the road. 


\section{Impedance of flows at drainage crossings (hypothesis 2a)}

Type of linear infrastructure was the key driver determining the occurrence of flow impedance $(p<0.001)$, with the most engineered infrastructure type (railway) associated with the highest probability of flow impedance ( $90 \%$, compared to $51 \%$ across other infrastructure types; Figure $3 c)$. At railway crossings, lower rainfall was associated with much higher rates of flow impedance $(98.5 \%$ where rainfall was $\leq 262 \mathrm{~mm} / \mathrm{a}$, compared with $50 \%$ where rainfall was $>262 \mathrm{~mm} / \mathrm{a}, \mathrm{p}<0.001)$.

\section{Diversion of flows at drainage crossings (hypothesis $2 b$ )}

Flow diversion was found to be more probable at linear infrastructure crossings where culverts occurred ( $88 \%$ compared to $64 \%$ in the absence of culverts; $p<0.001$ ). Annual average rainfall was the next key driver, showing a significant interaction with culvert presence (Appendix 5 Figure A5.1b).

\section{Flow concentration at drainage crossings (hypothesis 2c)}

Flow concentration was the most frequently observed impact of linear infrastructure on ephemeral drainage lines. The classification tree based on type of linear infrastructure alone showed a stronger association between flow concentration and linear infrastructure with higher levels of engineering (railways, paved roads, unpaved roads and major tracks), compared to minor tracks ( $p=0.005)$. In the tree derived from the broader variable set, rainfall emerged as the primary determinant of flow concentration, with concentration more likely where rainfall is lower ( $\leq 263 \mathrm{~mm}, p=0.013$ ) (Figure $3 d$ ). In lower-rainfall areas, the probability of observing flow concentration is highest where there is a culvert, and lowest where the fractional cover of bare soil is low $(\leq 28 \%, p=0.019)$.

\section{Channel initiation at drainage crossings (hypothesis 2d)}

Overall, culvert presence was the primary driver of new channel formation, with new channels formed at $45 \%$ of crossings with culverts, and only $22 \%$ of crossings without culverts $(p<0.001$, Appendix 5, Figure A5.1c). Where type of linear infrastructure was considered alone, railways were the key predictor of new channel initiation $(p<0.001)$; all railway crossings had culverts. 
a)



b)


c)



Flow impedance

d)

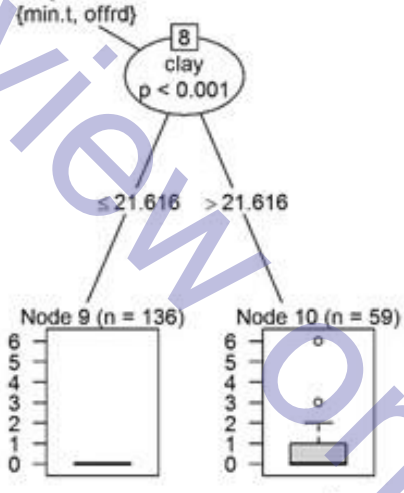

Flow concentration


Figure 3: Conditional inference trees showing the interactive effects of the main variables that explain some of the impacts of linear infrastructure on surface hydrology in the Great Western Woodlands. The trees show the grouping of sites into categories with statistically similar expected values of the response variable, using values or levels of the key predictor variables, as identified by the tree-building (recursive partitioning) process. Box and whisker plots show 
median and range of predictions for each prediction category. a) Regression tree of key predictors of erosional feature frequency in the landscape: Two erosional features per $\mathrm{km}$ are predicted where there is either pastoral tenure $(\mathrm{Y})$ or evidence of feral cattle (F). Where evidence of grazing is not apparent (0), linear infrastructure presence is the next predictor, with a median of zero erosional features where there is no infrastructure (offrd). In the presence of infrastructure (i.e. major tracks - maj.t and minor tracks - min.t), topographic slope (slope), average annual precipitation (rain), and soil clay proportion (clay) all significantly increase the expected frequency of erosional features. b) Regression tree showing the key predictors of pooling frequency within the landscape: here rainfall is the primary predictor with more pooling in areas that receive average annual precipitation over $\mathbf{2 7 7} \mathbf{~ m m}$ per year; infrastructure type (inf) again is the secondary predictor: in wetter areas, there is a clear differentiation between both major and minor tracks and off-road areas, with the latter having significantly lower pooling frequencies. In drier areas major tracks have a significantly higher pooling frequency than either minor tracks or off-road areas, but soil clay content and slope moderate predicted frequencies. c) classification tree showing the probability of observing flow impedance at a linear infrastructure crossing of an ephemeral streamline: railways (rail) have a greater likelihood of causing impedance than other infrastructure types, particularly where average annual rainfall is lower than $\mathbf{2 6 2} \mathbf{~ m m}$. d) classification tree showing probabilities of observing flow concentration at a linear infrastructure crossing of an ephemeral streamline: flows are more likely to be concentrated when they are lower to begin with (as indicated by average annual precipitation), where there is a culvert, and greater proportion bare soil (baresoil).

\section{Ephemeral drainage line assessments of case examples}

The ephemeral drainage line assessments provided further information on how linear infrastructure impacts on hydrology and stream stability can manifest. Figure 4 a shows an instance where interception and diversion of sheetflow from upslope, combined with excess on-road water, have breached the road zone at a low point and produced an eroded, unstable drainage line. Figure $4 \mathrm{~b}$ shows an existing stream that is largely stable upstream from a track, but very unstable on and downstream from it, with some upstream advancement of erosion from the track. This scenario is likely caused by concentration of flows along and by the track, and may also have been exacerbated by cattle that have often been observed along tracks in this area, which is a pastoral station. 

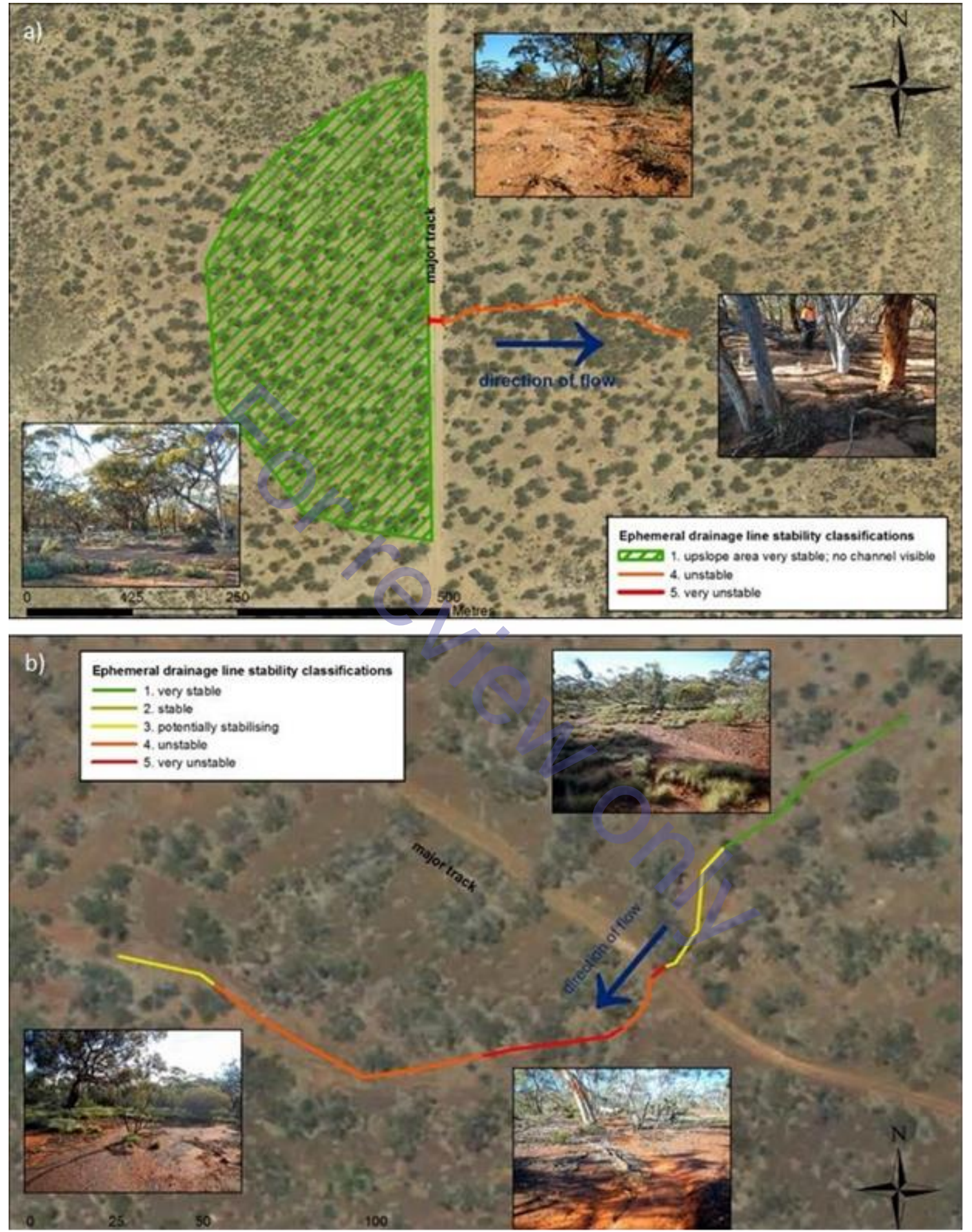

Figure 4: Ephemeral drainage-line assessment case studies. a) A new channel initiated by latitudinal redistribution of sheetflow from the upslope area, excess water generated by poor infiltration and/or flow concentration and channelling on and by the track. b) a stream in which flows from a track were concentrated and caused chronic erosion downstream of the road and for a shorter distance upstream. 


\subsection{Significance of impacts across the study area}

Raiter et al. (2017) estimated that a total of 149, $820 \mathrm{~km}$ of linear infrastructure exist in the GWW, of which $138,311 \mathrm{~km}$ are major or minor tracks. Assuming that there is consistency in the formation of such features (i.e. not accounting the effects of environmental variables), we estimate that approximately 146,000 erosional features ( $95 \%$ conf. int.: $135,000-158,000)$ and 96,000 pooling features (95\% conf. int.: 84,000-107,000) would occur along this length of tracks. We could not calculate the corresponding figure for roads and railways due to regular maintenance of these types of linear infrastructure (which would have obscured evidence of altered water movement and hence led us to exclude them from the analysis). Based on observed rates, we further estimate that there may be approximately 38,000 linear infrastructure crossings of ephemeral streamlines, of which flow impedance would occur at approximately 24,000 sites; flow diversion at 28,000 sites and flow concentration at 29,000 sites, along with 12,000 instances of new channel initiation.

\section{Discussion}

\subsection{Hydrological impacts of linear infrastructure}

We found that alterations in surface water movement associated with linear infrastructure are numerous and pervasive, even in the relatively flat, low rainfall landscapes of the GWW. Confirming our first hypothesis, we found that linear infrastructure is a major driver of erosion and pooling; with erosion and pooling five and six times more likely to occur on-road than off-road, respectively. Erosion severity was also significantly greater in the presence of linear infrastructure. These findings are consistent with other research that has pointed to a strong association between road networks, erosion, and surface water magnification in a variety of environments (Duniway and Herrick, 2013; Duniway et al., 2010; Jones et al., 2000; Keshkamat et al., 2013).

Also in agreement with the literature (Duniway and Herrick, 2011; Jones et al., 2000; Katz et al., 2014), we found that linear infrastructure has widespread impacts on ephemeral streamflows, with some alteration to flows observed in $98 \%$ of cases where infrastructure crosses a streamline. Confirming our second hypothesis, the more-engineered types of linear infrastructure had stronger associations with flow impedance, diversion and concentration, and channel initiation, compared to less-engineered infrastructure, although even the less-engineered types of linear infrastructure caused some impacts in most cases. Engineered solutions to hydrological issues (e.g. culverts) were frequent along more-engineered infrastructure, and although they provided many benefits (e.g. allowing streamflows to cross infrastructure), highly engineered infrastructure was still associated with many alterations to streamflows (e.g. mitre drains often create artificially wet areas (Figure 2c). These associations are most likely due to the changes in surface morphology and infrastructure height relative to surrounding ground and stream channel levels.

Other predictors of hydrological impacts included grazing, slope, precipitation, soil clay proportion and erodibility, and bare soil percentages. Interactions between the two main anthropogenic factors grazing and linear infrastructure - have not been demonstrated to date in the literature, although such interactions have been hypothesised to occur, and have been observed for vegetation change by Okayasu et al. (2007). Such interactions can result in ecological tipping points being reached (Bestelmeyer et al., 2015; Burnside et al., 1995). 
The case studies exemplified some of the impacts observed and highlighted the likelihood of multiple road impacts (e.g. poor infiltration and sheetflow interception) acting in synergy to effect changes that extend far beyond the linear infrastructure corridor. Such interactions have been described by others such as Duniway and Herrick (2011).

\subsection{Extent and wider consequences of linear infrastructure impacts on landscape hydrology}

To our knowledge, this study is the first to characterise and quantify the broad-scale impacts of linear infrastructure networks on surface and near-surface hydrology of a semi-arid region. This work has global relevance given the large areas of water-limited environments on earth, and the ubiquity and rapid expansion of linear infrastructure more generally. The estimated 335,000 occurrences of linear infrastructure impacts on surface water movement projected for the GWW are substantial (albeit an underestimate), and similar situations are likely to be unfolding in other areas worldwide.

These impacts have important consequences given that water availability is the main constraint on biological activity in arid and semi-arid ecosystems, which cover more than a third of the Earth's land surface area (Nielsen and Ball, 2015). For example, increased water availability in proximity to linear infrastructure has been noted to increase vegetation greenness, productivity and fecundity (Klöcker et al., 2006; Lamont et al., 1994a; Lamont et al., 1994b). Such phenomena have had flow-on effects on ecological processes, including near-road flowering times, species hybridisation, and herbivory; and have also resulted in increased mortality from vehicle collision for herbivores attracted to greener near-road vegetation (Klöcker et al., 2006; Lamont et al., 2003). Conversely, downslope water starvation or erosion can severely limit many of these same processes, reduce habitat viability for dependent species and diminish stream condition.

Linear infrastructure impacts may also interact synergistically with other global changes. For example, where linear infrastructure intercepts and/or diverts overland sheetflow and this has an aridifying effect downslope, this effect may exacerbate any impacts of drying and increases of temperature that may occur as a result of climate change. Such climate chance impacts are likely to occur in the GWW in the next half-century (Prober et al., 2012), as well as in other semi-arid regions such as in the Mediterranean Basin and Mexico (Herrera-Pantoja and Hiscock, 2015; Miranda et al., 2011).

\subsection{Management and policy implications}

Many of the impacts identified here are impacts that tend to fall through the gaps of impact evaluations and mitigation strategies, despite important ramifications for water availability, soil, nutrient and organic matter conservation, ecosystem productivity, dependent vegetation and affected fauna (Duniway and Herrick, 2011; Raiter et al., 2014). Still, there is substantial scope for mitigating these impacts by limiting linear infrastructure networks, integrating understandings of hydrological impacts into planning of linear infrastructure developments, and implementing hydrologically considerate design principles.

Firstly, hydrological impacts of linear infrastructure need to be incorporated as comprehensively as possible into environmental impact assessments, evaluations, land-use or conservation plans, and mitigation strategies. There do remain areas with very low infrastructure densities and these in particular need to be protected from further impacts. Developments likely to cause unacceptable impacts should be avoided, and the proliferation of linear infrastructure networks should be limited. This is particularly important for managing the cumulative impacts of multiple developments, such as 
unpaved vehicle tracks, which may be by far the most numerous in the landscape. Impacts resulting from new linear infrastructure developments that are approved could be partly offset with strategic consolidation of existing linear infrastructure networks (such as rehabilitation of unused vehicle tracks) where possible to complement such efforts. Rehabilitation of unused tracks and roads may also form an essential part of soil conservation or erosion mitigation programs in grazed landscapes. The type of linear infrastructure planned should also be appropriate for its use (Keshkamat et al., 2012).

Secondly, the methodology presented here could be used to improve planning of linear infrastructure networks on a landscape scale, by elucidating the key environmental drivers of hydrological impacts for use in impact mitigation. Risk maps could be created to identify parts of landscapes with the greatest likelihood of hydrological impacts (e.g. areas with greatest slopes or more erodible soil), and linear infrastructure could be aligned on routes that minimise these potential impacts. Likewise, track rehabilitation programs, as mentioned above, could be prioritised according to these risk maps.

Careful consideration is required to ensure that the mitigation of hydrological impacts does not create or exacerbate other impacts, such as disproportionately affecting a particular vegetation type that grows in parts of the landscape deemed to be less susceptible to hydrological impacts by concentrating new roads in that part of the landscape.

Next, hydrologically considerate linear infrastructure design and engineering (or retrofitting) are critical for minimizing the hydrological impacts of linear infrastructure. Components of hydrologically considerate linear infrastructure design are covered in some road planning manuals (e.g. Engineering and Technology Division, 2010; Roadway Engineering Group, 2014) and individual projects (e.g. Aquaterra, 2009; Bangladesh Railway, 2015; Fortescue Metals Group Ltd, 2008), but further development and more widespread implementation of such practices are needed.

Hydrologically considerate protocols need to consider the type, drainage, and orientation of infrastructure; the infrastructure elevation relative to ground level, ditches; windrows (built-up material on the edge of bladed or graded roads), and associated earthworks. Culverts could be installed frequently where appropriate and be constructed to ensure that channel width and elevation change are as consistent with the natural channel as possible, and/or floodways should be used where feasible, to minimise flow impedance and concentration. Where suitable, culverts and mitre drains can be designed to encourage any concentrated flows to become sheetflow and prevent stream channel initiation (Office of Environment and Heritage, 2012). Vehicle tracks can be constructed without lowering the road surface below the surrounding ground level to prevent water flowing along in the road (e.g. Figure $2 b$ ).

Lastly, further research is required to better understand and quantify the ramifications of the impacts reported here, and potential interactions with other change drivers. Such research should also take into account potential effects and ramifications of linear infrastructure on groundwater depths and any feedback loops. Additionally, research on cost-effective solutions to hydrologically considerate road design and engineering challenges is important for the development of these approaches and improving their implementation.

\section{Conclusion}

This research represents the first field-based, region-wide quantification of surface hydrology impacts associated with linear infrastructure. We discovered extensive evidence of impacts of linear 
infrastructure on both ephemeral streamflow, and water movement within the landscape in general, and associations between these and infrastructure type, land use, culvert presence, soil properties, topographic factors, and rainfall.

Impacts of linear infrastructure on surface hydrology could be mitigated by limiting the extent of linear infrastructure, incorporating understandings of environmental factors affecting susceptibility to impacts into broad-scale network planning, and developing and implementing hydrologically considerate design.

In landscapes where ecological processes function relatively well, maintaining their function by preventing anthropogenic degradation is often the highest priority and lowest risk conservation strategy (e.g. Prober et al., 2012). Maintaining natural water flow and infiltration as well as soil stability through more selective development, design, maintenance and restoration of linear infrastructure is an essential component of such an approach, and could be particularly important for mitigating climate change effects.

\section{Acknowledgements}

This work was supported by The Wilderness Society, Gondwana Link, the Gledden Postgraduate Research Scholarship, Australian Research Council Centre of Excellence for Environmental Decisions, the Natural Environmental Research Program Environmental Decisions Hub, and the Great Western Woodlands Supersite, part of Australia's Terrestrial Ecosystem Research Network.

We thank Carl Gosper, Colin Leek and Leonie Valentine for constructive comments on earlier versions of this manuscript and are grateful to Bridget Johnson for her assistance in field data collection. Cliffs Natural Resources provided in-kind support in the field and PJ Waddell provided initial ideas that inspired this investigation. All work was carried out under Department of Parks and Wildlife Regulation 4 permits CE003548 and CE004036.

\section{Literature cited}

Aquaterra, 2009. Oakajee Port and Rail development: surface water management. Oakajee Port \& Rail, Perth, Australia, p. 57.

Bangladesh Railway, 2015. Feasibility study, detailed design and tendering services for construction of dual gauge double rail line and conversion of existing rail line into dual gauge between Akhaura and Laksam: Environmental Impact Assessment. Ministry of Railways, Dhaka, Bangladesh.

Beard, J.S., Beeston, G.R., Harvey, J.M., Hopkins, A.J.M., D.P., S., 2013. The vegetation of Western Australia at the 1:3000 000 scale Explanatory memoir. Conservation Science Western Australia 9, 1-152.

Berry, S., Keith, H., Mackey, B., Brookhouse, M., Jonson, J., 2010. Green carbon: the role of natural forests in carbon storage. Part 2. Biomass carbon stocks in the Great Western Woodlands. The Fenner School of Environment and Society, Australian National University E Press, Canberra, Australia.

Bestelmeyer, B.T., Okin, G.S., Duniway, M.C., Archer, S.R., Sayre, N.F., Williamson, J.C., Herrick, J.E., 2015. Desertification, land use, and the transformation of global drylands. Frontiers in Ecology and the Environment 13, 28-36.

Beyer, H.L., 2012. Geospatial Modelling Environment (Version 0.7.3.0), available at http://www.spatialecology.com/gme. Spatial Ecology. 
Braimbridge, M., Commander, P., 2005. The Wheatbelt's ancient rivers, Water Notes for River Management. Department of Environment, Government of Western Australia, Perth, W. Australia, pp. 1-6.

Bruijnzeel, L., Vertessy, R., 2004. Hydrology: Impacts of forest management on streamflow, in: Burley, J., Evans, J., Youngquist, J. (Eds.), Encyclopedia of Forest Sciences, 1st ed. Academic Press, pp. 358-366.

Burnside, D.G., Holm, A., Payne, A., Wilson, G., 1995. Reading the rangeland: a guide to the arid shrublands of Western Australia. Department of Agriculture, Western Australia, Perth.

Donaldson, A., Bennett, A.F., Victoria, P., 2004. Ecological effects of roads: Implications for the internal fragmentation of Australian parks and reserves. Parks Victoria.

Duniway, M.C., Herrick, J.E., 2011. Disentangling road network impacts: the need for a holistic approach. Journal of Soil and Water Conservation 66, 31A-36A.

Duniway, M.C., Herrick, J.E., 2013. Assessing impacts of roads: Application of a standard assessment protocol. Rangeland Ecology \& Management 66, 364-375.

Duniway, M.C., Herrick, J.E., Pyke, D.A., Toledo P, D., 2010. Assessing transportation infrastructure impacts on rangelands: test of a standard rangeland assessment protocol. Rangeland Ecology \& Management 63, 524536.

Engineering and Technology Division, 2010. Road Drainage Manual: a guide to the planning, design, operation and maintenance of road drainage infrastructure. Department of Transport and Main Roads, State of Queensland, Brisbane.

Fortescue Metals Group Ltd, 2008. Pilbara Iron Ore and Infrastructure Project: Rail Corridor surface water management plan.

Herrera-Pantoja, M., Hiscock, K.M., 2015. Projected impacts of climate change on water availability indicators in a semi-arid region of central Mexico. Environmental Science \& Policy 54, 81-89.

Hothorn, T., Hornik, K., Strobl, C., Zeileis, A., 2017. Package 'party': A Laboratory for Recursive Partytioning, 1.2-3 ed. The R Project for Statistical Computing.

Hothorn, T., Hornik, K., Zeileis, A., 2006. Unbiased recursive partitioning: A conditional inference framework. Journal of Computational and Graphical Statistics 15, 651-674.

Huang, P.-F., Wang, W.-L., Luo, T., Wang, Z., Wang, Z.-L., Li, R., 2013. Analysis of hydrodynamics parameters of runoff erosion and sediment-yielding on unpaved road. Ying Yong Sheng tai xue bao $=$ The Journal of Applied Ecology 24, 497-502.

James, G., Witten, D., Hastie, T., Tibshirani, R., 2013. An introduction to statistical learning. Springer.

Jones, J.A., Swanson, F.J., Wemple, B.C., Snyder, K.U., 2000. Effects of roads on hydrology, geomorphology, and disturbance patches in stream networks. Conservation Biology 14, 76-85.

Karlson, M., Mortberg, U., 2015. A spatial ecological assessment of fragmentation and disturbance effects of the Swedish road network. Landscape and Urban Planning 134, 53-65.

Katz, H.A., Daniels, J.M., Ryan, S., 2014. Slope-area thresholds of road-induced gully erosion and consequent hillslope-channel interactions. Earth Surf. Process. Landf. 39, 285-295.

Keshkamat, S., Tsendbazar, N., Zuidgeest, M.H., van der Veen, A., de Leeuw, J., 2012. The environmental impact of not having paved roads in arid regions: An example from Mongolia. AMBIO: A Journal of the Human Environment 41, 202-205.

Keshkamat, S.S., Tsendbazar, N.E., Zuidgeest, M.H.P., Shiirev-Adiya, S., van der Veen, A., van Maarseveen, M., 2013. Understanding transportation-caused rangeland damage in Mongolia. Journal of Environmental Management 114, 433-444.

King, J.G., Tennyson, L.C., 1984. Alteration of streamflow characteristics following road construction in north central Idaho. Water Resources Research 20, 1159-1163. 
Klöcker, U., Croft, D.B., Ramp, D., 2006. Frequency and causes of kangaroo-vehicle collisions on an Australian outback highway. Wildlife Res 33, 5-15.

Lamont, B.B., He, T., Enright, N.J., Krauss, S.L., Miller, B.P., 2003. Anthropogenic disturbance promotes hybridization between Banksia species by altering their biology. Journal of Evolutionary Biology 16, 551-557.

Lamont, B.B., Rees, R.G., Witkowski, E., Whitten, V.A., 1994a. Comparative size, fecundity and ecophysiology of roadside plants of Banksia hookeriana. Journal of Applied Ecology 31, 137-144.

Lamont, B.B., Written, V.A., Witkowski, E.T.F., Rees, R.G., Enright, N.J., 1994b. Regional and local (road verge) effects on size and fecundity in Banksia menziesii. Australian Journal of Ecology 19, 197-205.

Luce, C.H., 2002. Hydrological processes and pathways affected by forest roads: what do we still need to learn? Hydrol. Process. 16, 2901-2904.

Main Roads Western Australia, 2015. Goldfields Esperance Traffic Digest 2009/10 - 2014/15. Main Roads Western Australia, Government of Western Australia, Perth, p. 7.

Miranda, J.D., Armas, C., Padilla, F.M., Pugnaire, F.I., 2011. Climatic change and rainfall patterns: Effects on semi-arid plant communities of the Iberian Southeast. J. Arid. Environ. 75, 1302-1309.

Montgomery, D.R., 1994. Road surface drainage, channel initiation, and slope instability. Water Resources Research 30, 1925-1932.

Nielsen, U.N., Ball, B.A., 2015. Impacts of altered precipitation regimes on soil communities and biogeochemistry in arid and semi-arid ecosystems. Global Change Biology 21, 1407-1421.

Office of Environment and Heritage, 2012. Erosion and sediment control on unsealed roads: a field guide for erosion and sediment control maintenance practices. Office of Environment and Heritage and Department of Premier and Cabinet, Sydney.

Okayasu, T., Muto, M., Jamsran, U., Takeuchi, K., 2007. Spatially heterogeneous impacts on rangeland after social system change in Mongolia. Land Degradation \& Development 18, 555-566.

Pechenick, A.M., Rizzo, D.M., Morrissey, L.A., Garvey, K.M., Underwood, K.L., Wemple, B.C., 2014. A multiscale statistical approach to assess the effects of connectivity of road and stream networks on geomorphic channel condition. Earth Surf. Process. Landf. 39, 1538-1549.

Prober, S., Thiele, K., Rundel, P., Yates, C., Berry, S., Byrne, M., Christidis, L., Gosper, C., Grierson, P., Lemson, K., Lyons, T., Macfarlane, C., O’Connor, M., Scott, J., Standish, R., Stock, W., van Etten, E., WardellJohnson, G., Watson, A., 2012. Facilitating adaptation of biodiversity to climate change: a conceptual framework applied to the world's largest Mediterranean-climate woodland. Climatic Change 110, 227-248.

R Core Team, 2015. R: A Language and Environment for Statistical Computing. R Foundation for Statistical Computing, Vienna, Austria.

Raiter, K.G., 2017. Roads versus flows in the Great Western Woodlands: surface-water insights into linear infrastructure effects, Mendeley Data, 1 ed, Elsevier; available at http://dx.doi.org/10.17632/b7xpsmwb4s.2.

Raiter, K.G., Possingham, H.P., Prober, S.M., Hobbs, R.J., 2014. Under the radar: mitigating enigmatic ecological impacts. Trends Ecol Evol 29, 635-644.

Raiter, K.G., Prober, S.M., Hobbs, R.J., Possingham, H.P., 2017. Lines in the sand: quantifying the cumulative development footprint in the world's largest remaining temperate woodland. Landscape Ecology 32, 1969-1986.

Roadway Engineering Group, 2014. Roadway Design Guidelines, in: Roadway Design Section (Ed.). Arizona Department of Transportation, Pheonix, USA, p. 406.

Song, Y.-y., Lu, Y., 2015. Decision tree methods: applications for classification and prediction. Shanghai Archives of Psychiatry 27, 130-135.

Switalski, T.A., Bissonette, J.A., DeLuca, T.H., Luce, C.H., Madej, M.A., 2004. Benefits and impacts of road removal. Frontiers in Ecology and the Environment 2, 21-28. 
Tongway, D., Hindley, N., 2004. Landscape function analysis: a system for monitoring rangeland function. African Journal of Range and Forage Science 21, 109-113.

Tongway, D., Ludwig, D., 2010. Ephemeral Drainage-line Assessments: Indicators of Stability - an appendix to the book: 'Restoring disturbed landscapes: putting principles into practice' by the same authors.

Waddell, P., Thomas, P., Findlater, P., 2012. A report on the Gascoyne River catchment following the 2010/11 flood events, Resource Management Technical Report 382. Department of Agriculture and Food, Western Australia, Perth, Western Australia.

Wang, C., Liu, S.L., Deng, L., Liu, Q., Yang, J.J., 2014. Road lateral disconnection and crossing impacts in river landscape of Lancang River Valley in Yunnan Province, China. Chin. Geogr. Sci. 24, 28-38.

Watson, A., Judd, S., Watson, J., Lam, A., Mackenzie, D., 2008. The extraordinary nature of the Great Western Woodlands. The Wilderness Society, Perth.

Webb, N.P., Herrick, J.E., Duniway, M.C., 2014. Ecological site-based assessments of wind and water erosion: informing accelerated soil erosion management in rangelands. Ecol Appl 24, 1405-1420.

Wemple, B.C., Jones, J.A., Grant, G.E., 1996. Channel network extension by logging roads in two basins, Western Cascades, Oregon. Water Resources Bulletin 32, 1195-1207.

Wischmeier, W., Mannering, J., 1969. Relation of soil properties to its erodibility. Soil Science Society of America Journal 33, 131-137.

Ziegler, A.D., Giambelluca, T.W., Sutherland, R.A., Vana, T.T., Nullet, M.A., 2001. Horton overland flow contribution to runoff on unpaved mountain roads: A case study in northern Thailand. Hydrol. Process. 15, 32033208 . 


\section{Supplementary material}

\section{Appendix 1: Examples of infrastructure and vegetation types}

Hydrological impacts were assessed along sections of (in order from most to least engineered): standard gauge railway, highways and other paved roads, graded, unpaved roads, major tracks (bladed unpaved roads) and minor tracks (unbladed vehicle tracks often consisting of two wheel ruts through largely undisturbed vegetation, or previously bladed tracks that have degraded to 'two wheel rut' condition).

In general, railways have multiple train passages per day and are regularly maintained to a high standard. Highways and other paved roads are bitumised and are regularly maintained to a high standard in most cases, with >1000 vehicles per day (highways) and 10's to 100s of vehicles per day (other paved roads; (Main Roads Western Australia, 2015). Unpaved roads may have similar traffic levels to paved roads but are not bitumised and all would receive maintenance although the regularity of maintenance may vary. Some unpaved roads may be closed to heavy vehicles or to all traffic for periods after rain to reduce damage to roads and the likelihood of bogging). Major tracks generally have low levels of traffic (estimated as a maximum of several vehicle per day on average) and are infrequently maintained. Minor tracks, for the most part, generally have very low levels of traffic (<10 vehicles per month) and are not maintained, except for special circumstances where, for example, a mining or exploration company is using the track and performs maintenance on eroded or otherwise damaged sections to make it usable. Both major and minor tracks are mostly not traversable in wet conditions, particularly in areas with clayey soils. 


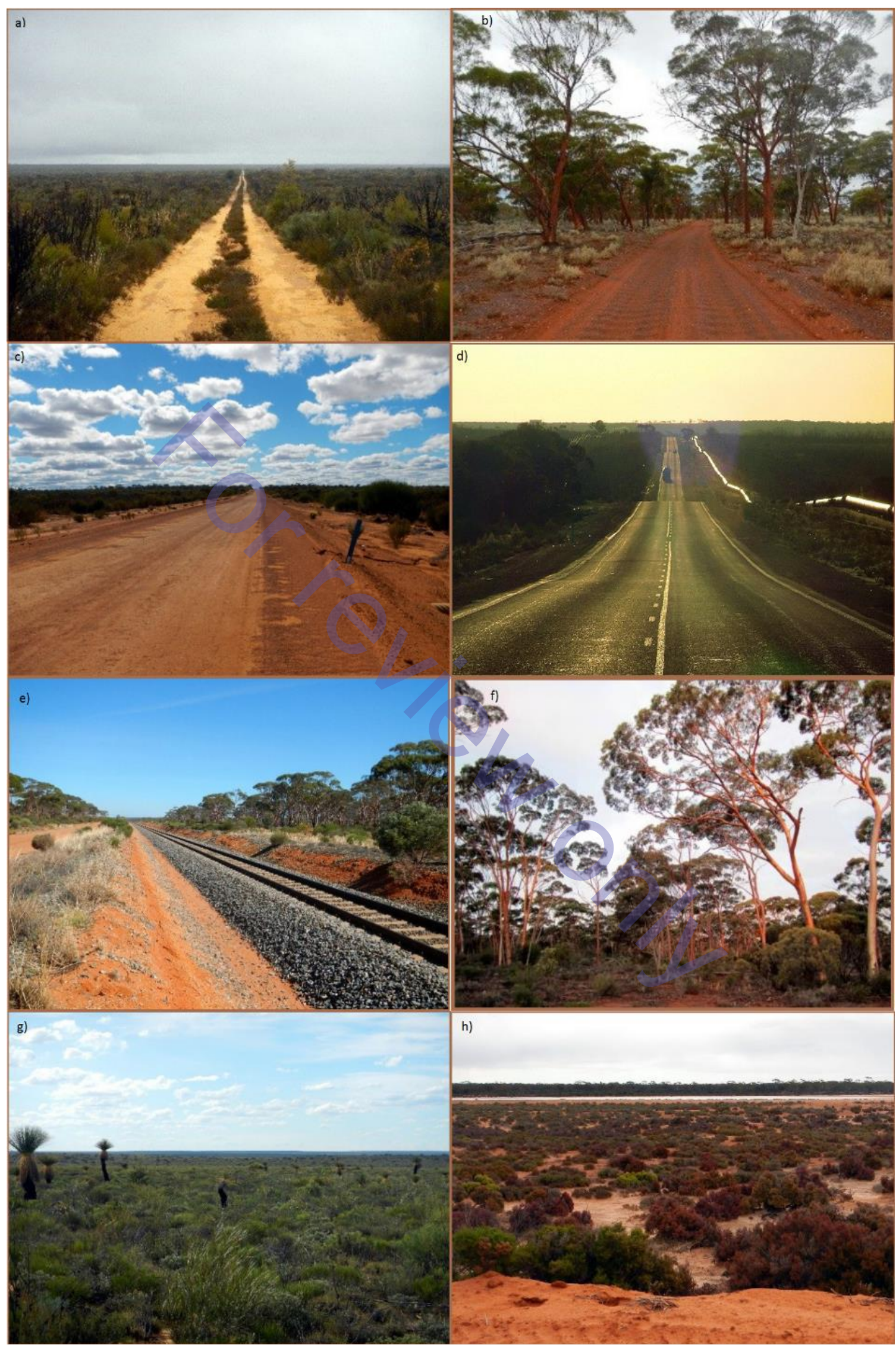

Figure A1.1: Examples of infrastructure and vegetation types observed in this study. a) minor track; b) major track; c) unpaved road; d) paved road; e) railway; f) woodland; g) shrubland; h) succulent steppe. 


\section{Appendix 2: Explanatory variables used in the analyses}

Table A2.1: Explanatory variables used in the analyses of erosion and pooling frequency, erosion severity, and the occurrence of flow impedance, diversion, concentration, and stream channel initiation at linear infrastructure crossings of ephemeral streams. Data was derived from field observations, sourced from Landgate (Western Australian Land Information Authority), and the Atlas of Living Australia (ALA, available at http://spatial.ala.org.au), or calculated from datasets provided by Geosciences Australia (GA). All topographic variables except 'topographic roughness' are based on hydrologically conditioned and drainage enforced 1 arc second digital elevation models (DEM-H) produced from the Shuttle Radar Topography Mission (derived hydrological version 1.0), provided by GA.

\begin{tabular}{|c|c|c|c|c|c|}
\hline $\begin{array}{l}\text { Name of } \\
\text { predictor }\end{array}$ & $\begin{array}{l}\text { Predictor } \\
\text { grouping }\end{array}$ & $\begin{array}{l}\text { Short } \\
\text { name }\end{array}$ & Source & Notes & $\begin{array}{l}\text { Included in } \\
\text { analyses }\end{array}$ \\
\hline $\begin{array}{l}\text { Type of linear } \\
\text { infrastructure }\end{array}$ & $\begin{array}{l}\text { Infrastructure } \\
\text { design }\end{array}$ & inf_type & $\begin{array}{l}\text { Field } \\
\text { observation }\end{array}$ & $\begin{array}{l}\text { Categories are (in order from most to least } \\
\text { engineered): railway, paved road, unpaved road, } \\
\text { major track, minor track, and off-road. }\end{array}$ & $\begin{array}{l}\text { All; note that } \\
\text { railways and } \\
\text { roads (both } \\
\text { paved and } \\
\text { unpaved) were } \\
\text { excluded from } \\
\text { the erosion and } \\
\text { pooling analysis } \\
\text { due to regular } \\
\text { maintenance and } \\
\text { resistant } \\
\text { materials that } \\
\text { would have } \\
\text { obscured } \\
\text { evidence of } \\
\text { altered water } \\
\text { movement. }\end{array}$ \\
\hline $\begin{array}{l}\text { Culvert } \\
\text { presence }\end{array}$ & $\begin{array}{l}\text { Infrastructure } \\
\text { design }\end{array}$ & culvert & $\begin{array}{l}\text { Field } \\
\text { observation }\end{array}$ & $\begin{array}{l}\text { All sizes and types of culvert included. Where } \\
\text { culverts were blocked this was noted, but not } \\
\text { included in the analysis }\end{array}$ & $\begin{array}{l}\text { Drainage } \\
\text { crossings: flow } \\
\text { impedance, } \\
\text { diversion and } \\
\text { concentration }\end{array}$ \\
\hline $\begin{array}{l}\text { Grazed status } \\
\text { (grazed or } \\
\text { ungrazed) }\end{array}$ & grazing & grazed & $\begin{array}{l}\text { Pastoral } \\
\text { tenure dataset } \\
\text { provided by } \\
\text { Landgate }\end{array}$ & $\begin{array}{l}\text { There is likely to have been variation in the intensity } \\
\text { of grazing within grazed areas; in addition, some } \\
\text { rogue cattle and other livestock now exist outside of } \\
\text { pastoral tenure; it was not possible to capture these } \\
\text { in the current analysis. }\end{array}$ & All \\
\hline $\begin{array}{l}\text { 300-m-focal- } \\
\text { median-of- } \\
\text { percent-slope } \\
\text { (\%) }\end{array}$ & topography & slope & $\begin{array}{l}\text { Calculated } \\
\text { from DEM-H } \\
\text { provided by } \\
\text { GA }\end{array}$ & $\begin{array}{l}\text { Extracted using 'extract multi values to points' tool } \\
\text { with central value of cell used - i.e. no bilinear } \\
\text { interpolation }\end{array}$ & All \\
\hline $\begin{array}{l}\text { Topographical } \\
\text { wetness index }\end{array}$ & topography & wetness & as above & $\begin{array}{l}\text { Calculated as } \log _{\mathrm{e}} \text { (specific catchment area/slope. } \\
\text { Extracted using 'extract multi values to points tool } \\
\text { with bilinear interpolation of values from adjacent } \\
\text { cells. }\end{array}$ & All \\
\hline
\end{tabular}




\begin{tabular}{|c|c|c|c|c|c|}
\hline $\begin{array}{l}\text { Name of } \\
\text { predictor }\end{array}$ & $\begin{array}{l}\text { Predictor } \\
\text { grouping }\end{array}$ & $\begin{array}{l}\text { Short } \\
\text { name }\end{array}$ & Source & Notes & $\begin{array}{l}\text { Included in } \\
\text { analyses }\end{array}$ \\
\hline $\begin{array}{l}\text { Localised } \\
\text { topographic } \\
\text { depression } \\
\text { (height above } \\
\text { sea level in } \mathrm{m} \text { ) }\end{array}$ & topography & dip & as above & $\begin{array}{l}\text { DEM-H divided by mean neighbourhood DEM-H, } \\
\text { calculated using focal Statistics tool in ArcGIS } 10.2 \text {, } \\
\text { using circular neighbourhood calculation with a } \\
\text { radius of } 3 \text { cells ( } 100 \mathrm{~m}) \text {. Both DEMH and focal } \\
\text { DEM-H extracted using 'extract multi values to } \\
\text { points tool with bilinear interpolation of values from } \\
\text { adjacent cells. }\end{array}$ & $\begin{array}{l}\text { All drainage } \\
\text { crossings and } \\
\text { erosion severity } \\
\text { analyses }\end{array}$ \\
\hline $\begin{array}{l}\text { Topographic } \\
\text { roughness }\end{array}$ & topography & roughness & ALA & Excluded due to collinearity with slope & - \\
\hline $\begin{array}{l}\text { Annual } \\
\text { precipitation } \\
(\mathrm{mm})\end{array}$ & climate & & $\begin{array}{l}\text { Climate } \\
\text { surface } \\
\text { modelling }\end{array}$ & $\begin{array}{l}\text { Surface modelled using ANUSPLIN and inputs from } \\
\text { ESOCLIM, BIOCLIM and GROCLIM on base } 9 \text { DEM, } \\
\text { ANUCLIM version 5.1. }\end{array}$ & All \\
\hline Annual mean & climate & evap & & Excluded due to collinearity with rain & - \\
\hline $\begin{array}{l}\text { Rainfall } \\
\text { erosivity (MJ } \\
\mathrm{mm} / \mathrm{ha} / \mathrm{hr} \text { ) }\end{array}$ & climate & erosivity & $\begin{array}{l}\text { CSIRO, based } \\
\text { on daily } \\
\text { rainfall data } \\
\text { provided by } \\
\text { Queensland } \\
\text { Department of } \\
\text { Natural } \\
\text { Resources, } \\
\text { accessed via } \\
\text { ALA }\end{array}$ & $\begin{array}{l}\text { Rainfall erosivity is defined as the mean annual sum } \\
\text { of individual storm erosion index values, EI30, } \\
\text { where } E \text { is the total storm kinetic energy and I30 is } \\
\text { the maximum 30-min rainfall intensity. Rainfall } \\
\text { surfaces at } 0.05 \text { degree (approx. } 5 \mathrm{~km} \text { ) resolution, } \\
\text { interpolated from daily rainfall data from 1980-1999 } \\
\underline{\text { http://spatial.ala.org.au/layers/more/erosivity }}\end{array}$ & All \\
\hline $\begin{array}{l}\text { Annual rainfall } \\
\text { seasonality }\end{array}$ & climate & seasonality & $\begin{array}{l}\text { CSIRO, } \\
\text { accessed via } \\
\text { ALA }\end{array}$ & $\begin{array}{l}\text { Index derived from two ratios. The ratio of warm } \\
\text { (Oct-Nov-Dec-Jan-Feb-Mar) to cool (Apr-May-Jun- } \\
\text { Jul-Aug-Sep) season rainfall totals (minus 1) are } \\
\text { assigned positive values when rainfall in the warm } \\
\text { season is greater than rainfall in the cool season. } \\
\text { The ratio of cool to warm season rainfall totals (plus } \\
\text { 1) are assigned negative values when rainfall in the } \\
\text { cool season is greater than rainfall in the warm } \\
\text { season. }\end{array}$ & - \\
\hline & & & & $\begin{array}{l}\text { Excluded in consolidating variables as exploratory } \\
\text { analyses showed low association between variable } \\
\text { and impacts, and there was no direct mechanism to } \\
\text { explain any association }\end{array}$ & \\
\hline $\begin{array}{l}\text { Average } \\
\text { runoff }\end{array}$ & climate & runoff & $\begin{array}{l}\text { CSIRO, } \\
\text { accessed via } \\
\text { ALA }\end{array}$ & $\begin{array}{l}\text { Mean annual runoff }(\mathrm{Ml} / 5 \mathrm{~km} \times 5 \mathrm{~km} \text { pixel), } \\
\text { Environmental (gridded) } 0.01 \text { degree }(\sim 1 \mathrm{~km}) \text {. } \\
\text { Excluded due to collinearity with rain }\end{array}$ & - \\
\hline
\end{tabular}




\begin{tabular}{|c|c|c|c|c|c|}
\hline $\begin{array}{l}\text { Name of } \\
\text { predictor }\end{array}$ & $\begin{array}{l}\text { Predictor } \\
\text { grouping }\end{array}$ & $\begin{array}{l}\text { Short } \\
\text { name }\end{array}$ & Source & Notes & $\begin{array}{l}\text { Included in } \\
\text { analyses }\end{array}$ \\
\hline $\begin{array}{l}\text { Soil erodibility } \\
\text { (K factor) }\end{array}$ & soil & erodibility & $\begin{array}{l}\text { Australian Soil } \\
\text { Resource } \\
\text { Information } \\
\text { System, } \\
\text { managed by } \\
\text { CSIRO. } \\
\text { Accessed via } \\
\text { ALA }\end{array}$ & $\begin{array}{l}\text { K factor represents the properties that affect a soil's } \\
\text { infiltration capacity and also its ability to resist } \\
\text { detachment and transport by rainfall and runoff, } \\
\text { including percentages of sand, silt, clay, and organic } \\
\text { matter; pH, structure and bulk density; pore space } \\
\text { filled by air; aggregation; parent material; and } \\
\text { various interactions of these variables (Wischmeier } \\
\text { and Mannering, 1969). Note that this covariate was } \\
\text { alternated with clay content and soil waterholding } \\
\text { capacity due to collinearity, to identify best } \\
\text { predictor for use in model. }\end{array}$ & $\begin{array}{l}\text { Erosion severity, } \\
\text { flow diversion, } \\
\text { concentration } \\
\text { and channel } \\
\text { initiation }\end{array}$ \\
\hline $\begin{array}{l}\text { Water holding } \\
\text { capacity }(\mathrm{mm} \\
\times \text { 1000) }\end{array}$ & soil & & $\begin{array}{l}\text { Australian Soil } \\
\text { Resource } \\
\text { Information } \\
\text { System, } \\
\text { managed by } \\
\text { CSIRO and } \\
\text { accessed via } \\
\text { ALA. }\end{array}$ & $\begin{array}{l}\text { Modelled from soil mapping of State and CSIRO } \\
\text { observations and presented as an area-weighted } \\
\text { mean } 1 \mathrm{~km} \text { grid. Note that this covariate was } \\
\text { alternated with clay content and soil erodibility due } \\
\text { to collinearity, to identify best predictor for use in } \\
\text { model. }\end{array}$ & $\begin{array}{l}\text { Excluded in final } \\
\text { trees due to } \\
\text { collinearity with } \\
\text { soil clay content }\end{array}$ \\
\hline $\begin{array}{l}\text { Solum average } \\
\text { median clay } \\
\text { content (\%) }\end{array}$ & soil & clay & $\begin{array}{l}\text { CSIRO } \\
\text { Ecosystem } \\
\text { Sciences, } \\
\text { accessed via } \\
\text { ALA }\end{array}$ & $\begin{array}{l}\text { Estimated median percentage clay content of } \\
\text { estimated soil texture. The estimated clay contents } \\
\text { for } 6 \text { texture groups by McDonald et al. (1990) were } \\
\text { used as a guide: interpreted values were increased } \\
\text { or decreased depending on the type of soil within a } \\
\text { group. Derived from McKenzie et al. (2000). The } \\
\text { solum average clay content is the A and B horizon } \\
\text { estimates weighted by the depth of each horizon. }\end{array}$ & $\begin{array}{l}\text { Erosion and } \\
\text { pooling } \\
\text { frequency; flow } \\
\text { impedance }\end{array}$ \\
\hline $\begin{array}{l}\text { Soil coarse } \\
\text { fragments }\end{array}$ & soil & soilcf & $\begin{array}{l}\text { CSIRO } \\
\text { Ecosystem } \\
\text { Sciences, } \\
\text { accessed via } \\
\text { ALA }\end{array}$ & $\begin{array}{l}\text { Excluded due to collinearity with water holding } \\
\text { capacity \& erodibility }\end{array}$ & - \\
\hline $\begin{array}{l}\text { Surface } \\
\text { Geology of } \\
\text { Australia }\end{array}$ & soil & Geology & $\begin{array}{l}\text { Surface } \\
\text { Geology of } \\
\text { Australia } \\
1: 1,000,000 \\
\text { Scale, } 2010 \\
\text { Edition, GA }\end{array}$ & $\begin{array}{l}\text { Excluded in consolidating variables as soil clay/water } \\
\text { holding capacity/erodibility are considered to better } \\
\text { represent surface soils and their hydrological } \\
\text { attributes }\end{array}$ & - \\
\hline $\begin{array}{l}\text { Vegetation - } \\
\text { Field }\end{array}$ & vegetation & veg & $\begin{array}{l}\text { Field } \\
\text { observation }\end{array}$ & $\begin{array}{l}\text { Vegetation observed was grouped into three broad } \\
\text { categories: woodland, shrubland, and succulent } \\
\text { steppe, based on Beard's vegetation classification } \\
\text { (Beard et al., 2013) }\end{array}$ & $\begin{array}{l}\text { All drainage } \\
\text { crossings } \\
\text { analyses. }\end{array}$ \\
\hline $\begin{array}{l}\text { Vegetation - } \\
\text { Beard }\end{array}$ & vegetation & bveg & $\begin{array}{l}\text { Beard's } \\
\text { vegetation } \\
\text { classification }\end{array}$ & From Beard et al. (2013) & $\begin{array}{l}\text { Erosion and } \\
\text { pooling } \\
\text { frequency, and } \\
\text { erosion severity } \\
\text { analyses }\end{array}$ \\
\hline
\end{tabular}




\begin{tabular}{|c|c|c|c|c|c|}
\hline $\begin{array}{l}\text { Name of } \\
\text { predictor }\end{array}$ & $\begin{array}{l}\text { Predictor } \\
\text { grouping }\end{array}$ & $\begin{array}{l}\text { Short } \\
\text { name }\end{array}$ & Source & Notes & $\begin{array}{l}\text { Included in } \\
\text { analyses }\end{array}$ \\
\hline $\begin{array}{l}\text { Normalised } \\
\text { difference } \\
\text { vegetation } \\
\text { index } \\
\left(\mathrm{NDVI}^{*} 100\right)\end{array}$ & vegetation & $n d v i$ & $\begin{array}{l}\text { Mean annual } \\
\text { NDVI } \\
\text { calculated } \\
\text { from MODIS } \\
250 \mathrm{~m} 16 \text { day } \\
\mathrm{NDVI} \\
\text { composites } \\
\text { derived from } \\
\text { bands } 1 \text { and } 2 \\
\text { of the MODIS } \\
\text { Terra satellite, } \\
\text { accessed via } \\
\text { ALA }\end{array}$ & Reference date is 2007. & All \\
\hline $\begin{array}{l}\text { Enhanced } \\
\text { vegetation } \\
\text { condition } \\
\text { index }\end{array}$ & vegetation & ev & $\begin{array}{l}\text { AusCover, } \\
\text { accessed via } \\
\text { ALA }\end{array}$ & $\begin{array}{l}\text { Global MODIS vegetation index designed to provide } \\
\text { consistent spatial and temporal comparisons of } \\
\text { vegetation conditions. Computed from } \\
\text { atmospherically corrected bi-directional surface } \\
\text { reflectances that have been masked for water, } \\
\text { clouds, heavy aerosols, and cloud shadows. }\end{array}$ & - \\
\hline $\begin{array}{l}\text { Fractional } \\
\text { Cover - Bare } \\
\text { Soil (\%) }\end{array}$ & vegetation & baresoil & $\begin{array}{l}\text { MODIS NBAR- } \\
\text { derived 16- } \\
\text { days fractional } \\
\text { cover of Bare } \\
\text { Soil (BS), } \\
\text { accessed via } \\
\text { ALA. }\end{array}$ & $\begin{array}{l}\text { Calculated as at 2012-03-05. Fractional cover } \\
\text { represents the exposed proportion of BS within } \\
\text { each pixel. In forested canopies, the photosynthetic } \\
\text { or non-photosynthetic portions of trees may } \\
\text { obscure those of the grass layer and/or bare soil. }\end{array}$ & All \\
\hline
\end{tabular}




\section{Appendix 3: Conditional inference tree model development}

\section{Data exploration}

Data exploration consisted of looking for missing data, data errors, and outliers in both predictor and response variables, assessing predictor variables for collinearity, and consolidating predictor variables to avoid crowding models, based on predictor relevance and initial predictor-response relationships using scatterplots boxplots, and correlation coefficients. Exploratory analyses also considered any biasing effects of the spatial and temporal aspects of sampling design, interactions, zero inflation, and the balance of categorical variables (also see Appendix 4). As classification and regression trees do not require distributional assumptions and can handle skewed data without requiring data transformation (Song and Lu, 2015), no data transformations were performed.

Some outliers were identified in the 'arelief', 'rain', 'runoff', 'ndvi', topographic wetness, and dip variables, but these points were all left in as investigation indicated that they all represented real data variation and not data errors. Some pairs of variables were identified as being collinear, where a correlation of $>0.6$ indicates collinearity. These were either alternated in models to identify the more powerful variable to use, or only one was selected for inclusion based on the presence of a direct mechanism to explain an association with the response.

\section{Conditional inference tree models}

For each response variable, conditional inference trees were first produced using only 'infrastructure type' as the predictor, to directly ascertain the effects of infrastructure type alone. Then, conditional inference trees were produced using the broader suite of possible predictors as follows for drainage crossings impacts:

$$
\begin{aligned}
& \text { impedance. } \text { tree }=\text { ctree }(\text { impedance } \sim \text { inf }+ \text { wetness }+ \text { dip }+ \text { rain }+ \text { slope }+ \text { erosivity } \quad+\text { veg }+ \text { ndvi }+ \\
& \text { baresoil + grazed + clay + culvert }, \quad \text { data }=d x) \\
& \text { diversion.tree }=\text { ctree }(\text { divert } \sim \text { inf }+ \text { wetness }+ \text { dip }+ \text { rain }+ \text { slope }+ \text { erosivity }+v e g+n d v i+\text { baresoil }+ \text { grazed } \\
& + \text { waterhold }+ \text { culvert }, \quad \text { data }=d x \text { ) } \\
& \text { concentration. } \text { tree }=\text { ctree }(\text { conc } \sim \text { inf }+ \text { wetness }+ \text { dip }+ \text { rain }+ \text { slope }+ \text { erosivity }+v e g+n d v i+\text { baresoil }+ \\
& \text { grazed + erodibility }+ \text { culvert }, \quad \text { data }=d x) \\
& \text { newchannel.tree }=\text { ctree }(\text { newchan } \sim \text { inf }+ \text { wetness }+ \text { dip }+ \text { rain }+ \text { slope }+ \text { erosivity }+v e g+n d v i+\text { baresoil + } \\
& \text { grazed }+ \text { culvert }+ \text { erodibility , } \quad \text { data }=d x)
\end{aligned}
$$

Where 'impedance.tree' is the conditional inference tree model for the occurrence of flow impedance at linear infrastructure crossings, 'diversion.tree' is the conditional inference tree model for the occurrence of flow diversion at linear infrastructure crossings, 'concentration.tree' is the conditional inference tree model for the occurrence of flow concentration at linear infrastructure crossings, and 'newchannel.tree' is the conditional inference tree model for the occurrence of new channel initiations at linear infrastructure crossings. The function 'ctree()' is the conditional inference tree building function of the 'party' package in R; 'impedance' is a binary integer indicating the presence or otherwise of impedance impacts at each site; 'inf' refers to the type of linear infrastructure present (i.e. railway, paved road, unpaved road, major track, minor track); 'wetness' refers to topographic wetness; 'dip' refers to localised topographic depression, 'rain' refers to average annual precipitation; 
'slope' refers to topographic slope; 'erosivity' refers to rainfall erosivity; 'veg' refers to vegetation type present based on field observations; ' $n d v i$ ' refers to normalised difference vegetation index; 'baresoil' refers to the percent of bare soil present; 'grazed' refers to pastoral status; 'clay' refers to the clay percentage in the soil; 'culvert' refers to the presence of a culvert; 'waterhold' refers to the water holding capacity of the soil; 'erodibility' refers to the soil erodibility (K factor); and ' $d x$ ' represents the full dataset of drainage crossings.

For erosion and pooling frequency, and pooling severity, trees based on the broader suite of variables were built using the following commands:

$$
\begin{aligned}
& \text { erosion.frequency.tree }=\text { ctree }(\text { no_eros } \sim \text { inf + slope + rain + erosivity + ndvi + clay + grazed, data }=\text { epk , } \\
& \text { controls }=\text { ctree_control }(\text { mincriterion }=0.99)) \\
& \text { pooling.frequency.tree }=\text { ctree }(\text { pools } \sim \text { inf }+ \text { slope }+ \text { rain }+ \text { erosivity }+n d v i+\text { clay }+ \text { grazed }, \text { data }=\text { epk, } \\
& \text { controls }=\text { ctree_control }(\text { mincriterion }=0.99)) \\
& \text { erosion.severity.tree }=\text { ctree }(\operatorname{sev} \sim \text { inf }+ \text { slope + rain + erosivity + wetness + bveg + erodibility + baresoil + } \\
& n d v i+\text { grazed }+ \text { dip }, \text { data }=e s, \text { controls }=\text { ctree_control }(\text { mincriterion }=0.99))
\end{aligned}
$$

Where 'erosion.frequency.tree' is the conditional inference tree model for the frequency of erosional features, 'pooling.frequency.tree' is the conditional inference tree for the frequency of pooling features, and 'erosion.severity.tree' is the conditional inference tree for the severity of erosional features observed. The function 'ctree()' is the conditional inference tree building function of the 'party' package in R; 'no_eros' refers to the number of erosional features within each kilometre-long section of landscape studied; 'pools' refers to the number of pooling features within each kilometrelong section of landscape studied; 'sev' refers to the severity of erosion observed at each erosional feature (1: rill to $5 \mathrm{~cm}$ deep, $>2 \mathrm{~m}$ long; 2 : rill to $15 \mathrm{~cm}$ deep, $>10 \mathrm{~m}$ long; 3 : rills to $30 \mathrm{~cm}$ deep, $>20 \mathrm{~m}$ long, 4: gullies deeper than $30 \mathrm{~cm}$ ). Amongst the predictor variables, 'inf' refers to the presence and type of linear infrastructure present (i.e. major track, minor track, or off-road); 'slope' refers to topographic slope; 'rain' refers to average annual precipitation; 'erosivity' refers to rainfall erosivity; 'ndvi' refers to normalised difference vegetation index; 'clay' refers to the clay percentage in the soil; 'grazed' refers to pastoral status; 'dip' refers to localised topographic depression, 'wetness' refers to topographic wetness; 'bveg' refers to vegetation type present based on Beard's vegetation data spatial layer; 'erodibility' refers to the soil erodibility (K factor); 'epk' represents the full dataset of erosion and pooling features quantified by kilometre sections of landscape transect, and 'es' represents the full dataset of erosional features showing erosional severity for each feature. The phrase 'controls = ctree_control(mincriterion $=0.99)$ ' specifies the minimum significance criterion for the association between the predictor and response variable; in this case it was set at 0.99 (i.e. $\mathrm{p}=0.01$ ).

The following except from the 'party' package documentation provides further details on the ctree function and the resultant model:

"Conditional inference trees estimate a regression relationship by binary recursive partitioning in a conditional inference framework. Roughly, the algorithm works as follows: 1) Test the global null hypothesis of independence between any of the input variables and the response (which may be multivariate as well). Stop if this hypothesis cannot be rejected. Otherwise select the input variable with strongest association to the response. This association is measured by a p-value corresponding to a test for the partial null hypothesis of a single input variable and the response. 2) Implement a binary split in the selected input 
variable. 3) Recursively repeat steps 1) and 2). The implementation utilizes a unified framework for conditional inference, or permutation tests, developed by Strasser and Weber (1999). The stop criterion in step 1) is either based on multiplicity adjusted p-values (testtype == "Bonferroni" or testtype == "MonteCarlo" in ctree_control), on the univariate $p$-values (testtype == "Univariate"), or on values of the test statistic (testtype == "Teststatistic"). In both cases, the criterion is maximized, i.e., 1 - pvalue is used. A split is implemented when the criterion exceeds the value given by mincriterion as specified in ctree_control. For example, when mincriterion $=0.95$, the $p$-value must be smaller than $\$ 0.05 \$$ in order to split this node. This statistical approach ensures that the right sized tree is grown and no form of pruning or crossvalidation or whatsoever is needed." (Hothorn et al., 2017)

The data was also modelled in two alternative ways to compare and verify model results and help in the assessment of the significance of predictor variables: using generalised linear models ('stats' package) and 'conventional' classification and regression trees ('tree' package, using cross-validation and pruning for choosing tree complexity). The results of these alternative models are not presented here.

\section{Model descriptions}

Model outputs, including test statistics for each tree node, are summarised in Table A3.1. Please note that criteria represent the $p$-value subtracted from 1; $p$-values for the associations between response variables and predictors are shown in the conditional inference trees themselves (see Figure 3 and Appendix 5).

Table A3.1 Model specifications and outputs

\begin{tabular}{|c|c|c|c|c|}
\hline  & Model & $\begin{array}{l}\text { Terminal } \\
\text { nodes for } \\
\text { full } \\
\text { model }\end{array}$ & Description of full model & $\begin{array}{l}\text { Number of } \\
\text { observations }\end{array}$ \\
\hline \multirow{12}{*}{ 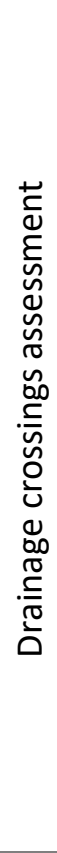 } & \multirow[t]{6}{*}{$\begin{array}{l}\text { Flow } \\
\text { impedance } \\
\text { impacts }\end{array}$} & \multirow[t]{6}{*}{3} & $\begin{array}{l}\text { 1) } \inf ==[\text { maj.t, } \min . t \text {, sld.rd, unsld.rd }] \text {; criterion }=1 \text {, statistic }= \\
42.881 \\
\text { 2)* weights }=205\end{array}$ & \multirow[t]{6}{*}{285} \\
\hline & & & 1) inf $==[$ rail $]$ & \\
\hline & & & 3) rain $<=262$; criterion $=1$, statistic $=26.625$ & \\
\hline & & & 4) $*$ weights $=66$ & \\
\hline & & & 3) rain $>262$ & \\
\hline & & & 5) $*$ weights $=14$ & \\
\hline & \multirow{6}{*}{$\begin{array}{l}\text { Flow } \\
\text { diversion } \\
\text { impacts }\end{array}$} & \multirow[t]{6}{*}{4} & 1) culvert $==[N]$; criterion $=1$, statistic $=19.449$ & \multirow[t]{6}{*}{285} \\
\hline & & & 2) rain $<=238 ;$ criterion $=0.954$, statistic $=8.314$ & \\
\hline & & & $3)^{*}$ weights $=22$ & \\
\hline & & & 2) rain $>238$ & \\
\hline & & & 4) $*$ weights $=150$ & \\
\hline & & & 1) culvert $==[\mathrm{Y}]$ & \\
\hline
\end{tabular}


5) rain $<=265$; criterion $=0.994$, statistic $=12.045$

$6)^{*}$ weights $=74$

5) rain $>265$

$$
\text { 7) } * \text { weights }=39
$$

Flow $\quad 4 \quad$ 1) rain $<=263 ;$ criterion $=0.987$, statistic $=14.941$ concentration impacts

2) culvert $==[N]$; criterion $=0.992$, statistic $=13.106$

3) baresoil $<=28$; criterion $=0.979$, statistic $=9.813$

4) $*$ weights $=11$

3) baresoil > 28

$5)^{*}$ weights $=100$

2) culvert $==[\mathrm{Y}]$

$6)^{*}$ weights $=73$

1) rain $>263$

7) $*$ weights $=101$

New channel 2 initiation

Erosional 7 frequency
1) culvert $==[Y]$; criterion $=1$, statistic $=18.595$

2)* weights $=113$

1) culvert $==[\mathrm{N}]$

$3)^{*}$ weights $=172$

1) grazed $==[F, P]$; criterion $=1$, statistic $=109.761$

2)* weights $=108$

1) grazed $==[0]$

3) inf $==[$ maj.t, min.t $] ;$ criterion $=1$, statistic $=77.258$

4) slope $<=2.09338$; criterion $=1$, statistic $=48.735$

5) rain $<=277$; criterion $=1$, statistic $=22.906$

6) clay $<=30 ;$ criterion $=1$, statistic $=17.153$

7) slope $<=1.2597$; criterion $=0.999$, statistic $=15.432$

8) $*$ weights $=113$

7) slope $>1.2597$

9) $*$ weights $=144$

6) clay $>30$

10) $*$ weights $=42$

5) rain $>277$

$11) *$ weights $=113$

4) slope > 2.09338

$12)^{*}$ weights $=73$

3) $\inf ==$ [offrd] 
$13)^{*}$ weights $=90$

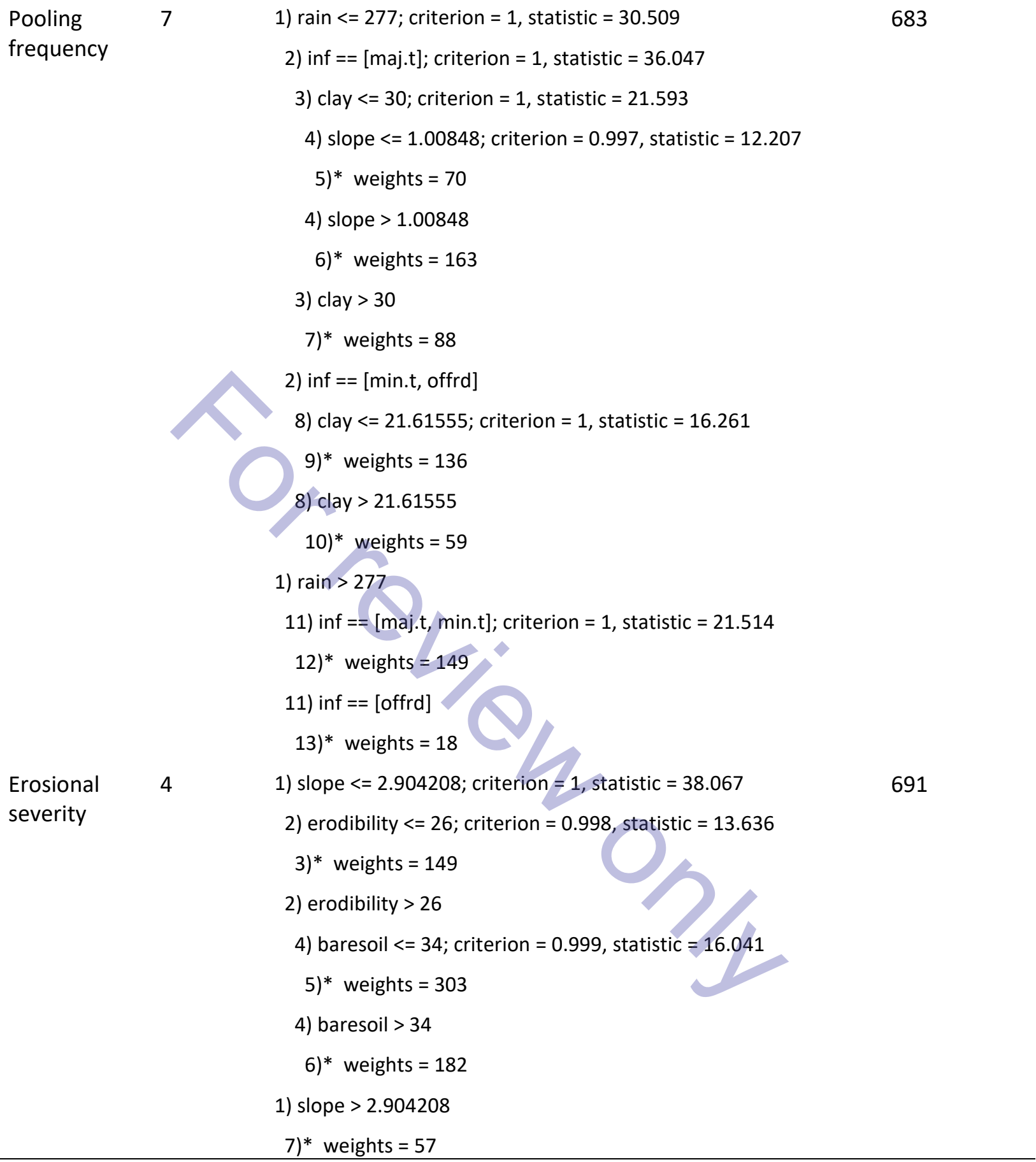

Note: maj.t $=$ major track, min.t $=$ minor track, sld.rd = paved (sealed) road, unsld.rd = unpaved (unsealed) road, offrd = off-road. 


\section{Appendix 4: Analysis of grazing effect within infrastructure categories}

This analysis was performed to test for possible compounding of the effects of linear infrastructure and grazing in the analyses of erosional and pooling frequency, as samples of the different grazing categories were not evenly distributed across the different types of linear infrastructure, as shown in Table A4.1.

Table A4.1 Sections and erosional features sampled within each grazing and linear infrastructure category for the analysis of erosion and pooling feature frequency

Kilometre-length transects

\begin{tabular}{|c|c|c|c|c|}
\hline & pastoral-grazed & feral-grazed & ungrazed & total \\
\hline major track & 80 & 17 & 269 & 366 \\
\hline minor track & 1 & 0 & 216 & 217 \\
\hline off-road & 0 & 10 & 90 & 100 \\
\hline total & 81 & & 575 & 683 \\
\hline \multicolumn{5}{|c|}{ Erosional features observed } \\
\hline & pastoral-grazed & feral-gr & ungr & total \\
\hline major track & 174 & 31 & 172 & 377 \\
\hline minor track & 5 & n.a. & 27 & 275 \\
\hline off-road & n.a. & 29 & 10 & 39 \\
\hline total & 179 & 60 & 452 & 691 \\
\hline
\end{tabular}

Cattle grazing (both on pastoral tenure and by feral cattle) was found to be a key driver of erosional feature severity (Figure 3a \& Figure A4.1a). Grazing was not identified as a key driver of pooling frequency nor erosion severity, although overall trends indicate increases in these variables in the presence of grazing (Figure A4.1b \& c). Box-plots and ANOVAs were used to confirm that these apparent trends are not due to compounding with types of linear infrastructure. Figure A4.2 shows erosion and pooling frequency and erosion severity by grazing category for each type of linear infrastructure. The overall trend of more frequent erosion in grazed areas is observed consistently within infrastructure categories. Similarly, pooling is more frequent in feral-grazed areas off-road and along major tracks, although it is not more frequent in pastoral-grazed areas. Erosion severity along major tracks is greatest in feral-grazed areas; intermediate in pastoral-grazed areas, and lowest in 
ungrazed areas. Severity in off-road areas is also greater, on average, where feral cattle occur, although the trend is not statistically significant.
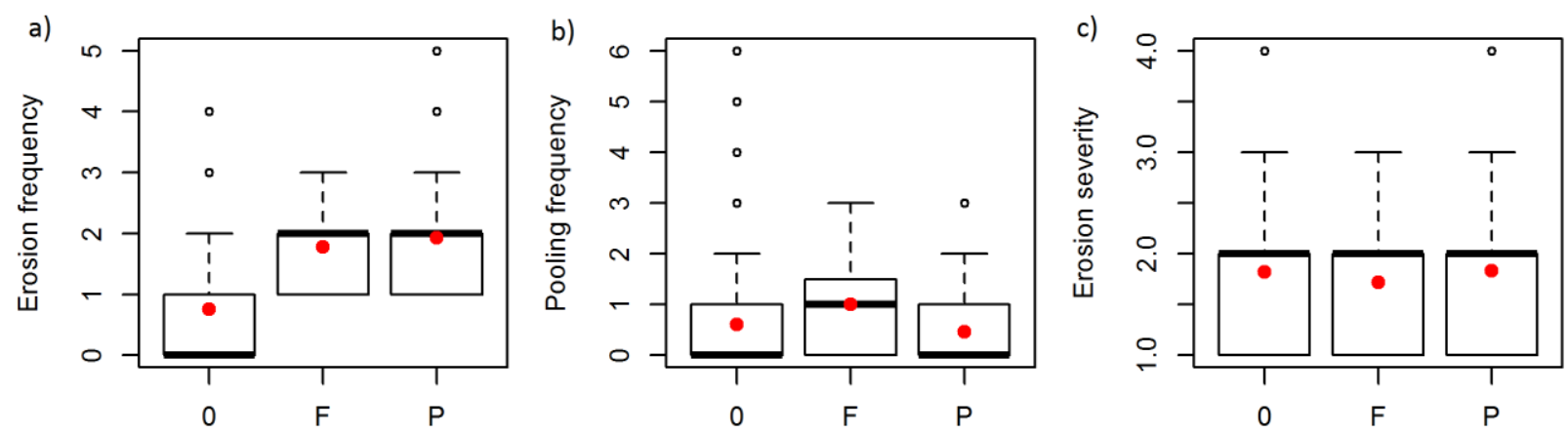

Grazing category: $0=$ ungrazed, $F=$ feral-grazed, $P=$ pastoral-grazed

Figure A4.1: Box plots showing evidence of altered water movement for the different grazing categories used in this analysis, with all linear infrastructure types pooled. a) Frequency of erosional features (features per km). b) Frequency of pooling features (pools per km). c) Severity of erosional features (scale of 1 to 4).

These results indicate that grazing is an independent driver of altered surface water movement, outside of any compounding effects of linear infrastructure. They also indicate that the occurrence of feral cattle in an area may be at least as strong a driver of erosion and water pooling as pastoral grazing - a somewhat surprising effect as feral grazing is considered to have occurred over a much shorter timeframe and possibly be less intense, albeit less managed. Further data would be needed to confirm the consistency of this trend. 

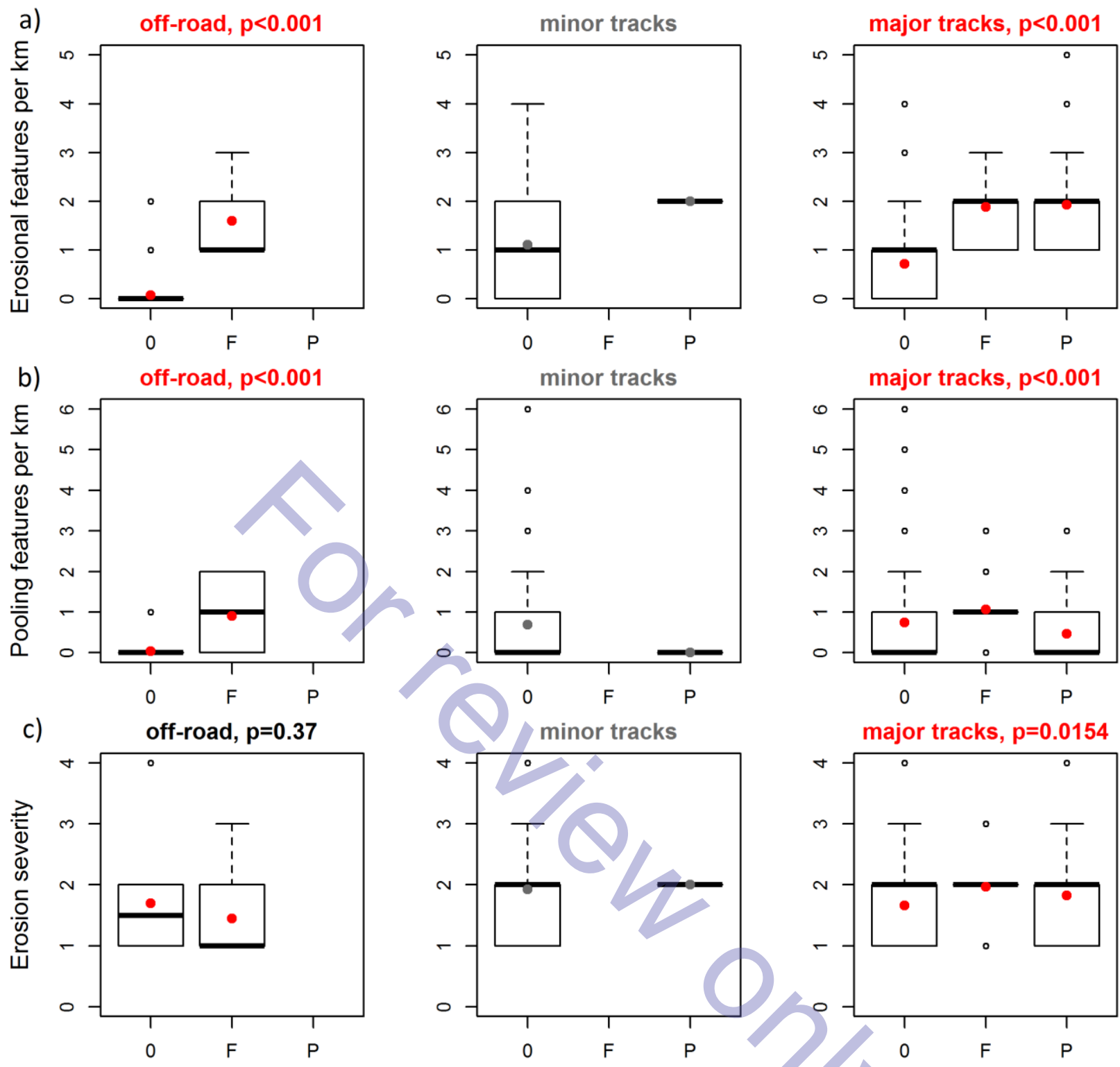

Grazing category: 0 = ungrazed, $F=$ feral-grazed, $P=$ pastoral-grazed

Figure A4.2: Boxplots showing evidence of altered water movement by category, for off-road areas and minor and major tracks. Minor tracks are included for completeness although there were insufficient data to analyse trends within this category; their titles and averages are shown in grey. Red text indicates significant differences between frequency of erosional features across grazing categories within each infrastructure type. Red points show averages. 


\section{Appendix 5: Additional conditional inference trees}

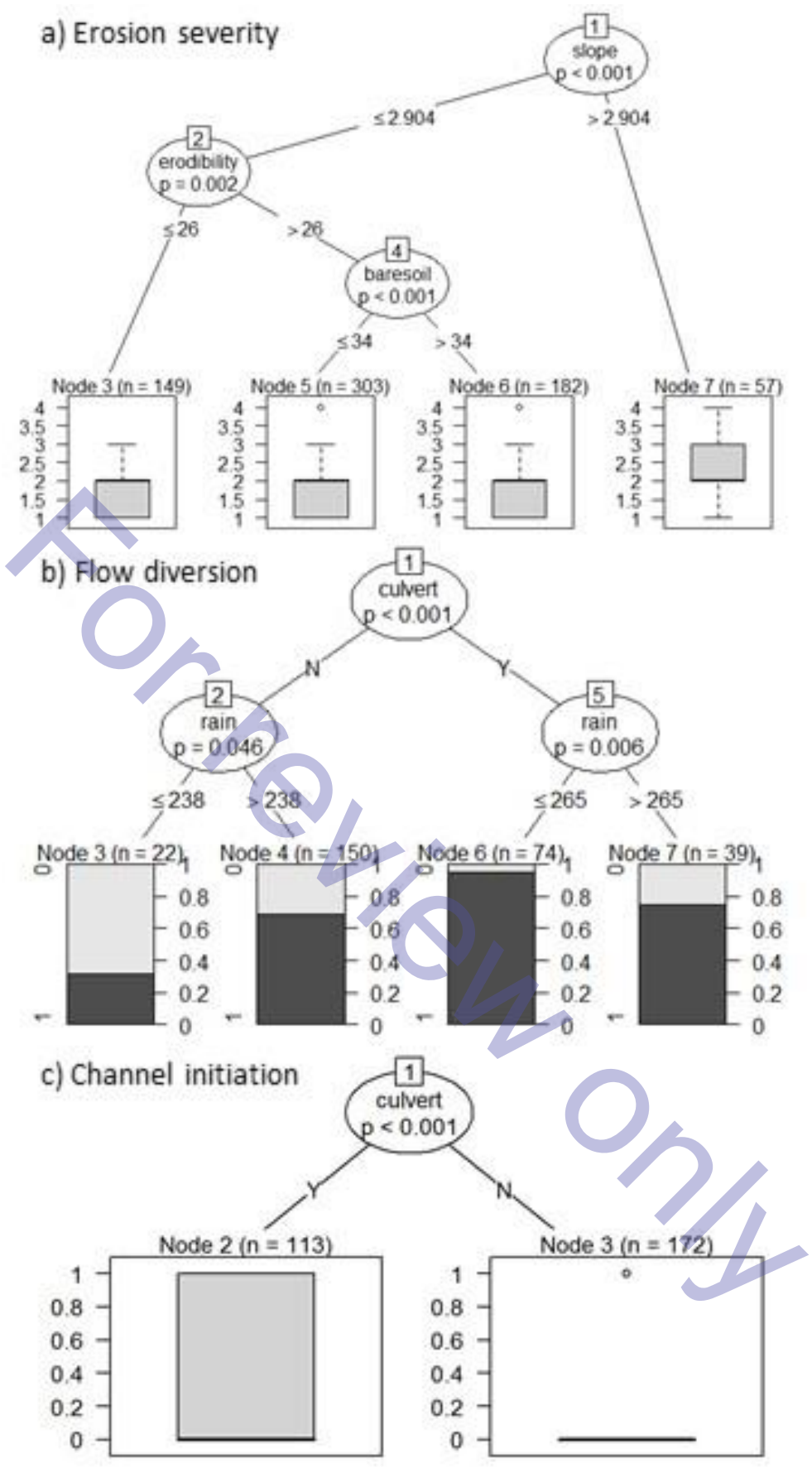

Figure A5.1: Additional conditional inference trees showing dominant drivers of hydrological impacts of linear infrastructure. a) Regression tree showing the positive associations of slope, soil erodibility, and proportion of bare soil with erosion severity. Erosion severity was also found to be significantly higher $(p=0.01409)$ on tracks compared with in off-road areas, however this variable is not included in the conditional inference tree. b) Classification tree showing the predicted probability of flow being diverted at a linear infrastructure crossing of an ephemeral streamline. The presence of a culvert is the strongest predictor, although this interacts with rainfall such that there is a greater probability of observing diverted flows where there is a culvert and rainfall is low, but a greater probability of observing flow diversion where there is no culvert and rainfall is relatively high..c) Classification tree showing predictions for channel initiation. Culvert presence was the key predictor of channel initiation. In most of these cases, major ditch- and embankment engineering works laterally redistribute any overland water movement and concentrate it through culverts and connected mitre drains, which lead to the formation of new stream channels. 